Joseph A. Clougherty

\title{
Antitrust Holdup Source, Cross-National Institutional Variation, and Corporate Political Strategy Implications for Domestic Mergers in a Global Context
}

SP II $2004-09$

June 2004

ISSN Nr. $0722-6748$

Research Area

Markets and Political Economy

Research Unit

Competitiveness and Industrial Change
Forschungsschwerpunkt

Markt und politische Ökonomie

Abteilung

Wettbewerbsfähigkeit und industrieller Wandel 
Zitierweise/Citation:

Joseph A. Clougherty, Antitrust Holdup Source, CrossNational Institutional Variation, and Corporate Political Strategy Implications for Domestic Mergers in a Global Context, Discussion Paper SP II 2004 - 09,

Wissenschaftszentrum Berlin, 2004.

Wissenschaftszentrum Berlin für Sozialforschung gGmbH, Reichpietschufer 50, 10785 Berlin, Germany, Tel. (030) 25491 - 0 Internet: www.wz-berlin.de 
Antitrust Holdup Source, Cross-National Institutional Variation, and Corporate Political Strategy Implications for Domestic Mergers in a Global Context

by Joseph A. Clougherty*

Managers are increasingly uncertain over the source (home-nation or foreignnation) of antitrust holdup for domestic mergers with significant international implications. I propose a conceptual framework that predicts the source of antitrust holdup for domestic mergers. Under idealized institutional assumptions, I find an industry's global competitiveness to be the primary driver behind holdup source: a contention supported by empirical tests based on the merger policies of 27 antitrust jurisdictions over the 1992-2000 period. I also relax the idealized institutional conditions to yield more precise propositions tailored to the cross-national environment for antitrust policy. Finally, I generate prescriptive propositions that yield implications for effective political strategies.

Keywords: Corporate Political Strategy; Non-Market Strategy; Merger Reviews; Antitrust Policy

JEL Classification: L40; M20; F14

I thank Douglas van den Berghe, Tom D'Aunno, Jean-Francois Hennart and Bongjin Kim, as well as seminar participants from the Department of Applied Economics \& Management at Cornell University, the Academy of International Business meetings in Puerto Rico, and the Strategic Management Society meetings in Paris for helpful comments in the development of this work. The Boston University School of Management also provided sanctuary during the drafting process. Postal Address: WZB; Research Unit: MP/CIC; Reichpietschufer 50; 10785 Berlin; Germany E-mail Address: Clougherty@wz-berlin.de 
„Ein institutioneller Ländervergleich von ,hold-up' durch Wettbewerbsbehörden in Fusionsverfahren und deren Implikationen für die Fusionsstrategien von globalen Unternehmen“"

Bei großen Fusionen, die für den internationalen Markt Bedeutung haben, stehen Manager zunehmend vor der Unsicherheit, im Vorfeld nicht erkennen zu können, ob die kartellrechtlichen Überprüfungen der Fusion eher im Heimatland oder im Ausland zu einem aus Unternehmenssicht negativen Ergebnis führen, also die Fusion abgelehnt oder nur unter restriktiven Auflagen genehmigt wird (,hold-up'). Hier wird ein konzeptioneller Ansatz entwickelt, mit dem sich vorhersagen lässt, welche der kartellrechtlichen Prüfungen zu dem restriktivsten Ergebnis führt. Unter idealisierten Annahmen über die institutionelle Ausgestaltung der nationalen Kartellbehörden lässt sich die theoretische Hypothese aufstellen, dass vor allem die weltweite Wettbewerbsfähigkeit einer Branche eine Rolle bei der Zuordnung des hold-upProblems spielt, was auch empirisch durch die Entscheidungen von 27 Kartellinstitutionen im Zeitraum von 1992-2000 bestätigt wird.

Die idealisierten institutionellen Bedingungen in den verschiedenen Ländern werden daraufhin aufgegeben, um exaktere und auf die tatsächlichen kartellrechtlichen Umgebungen in den einzelnen Ländern abgestimmte Empfehlungen formulieren zu können. Für die Unternehmen werden schließlich Empfehlungen für effektive politische Fusionsstrategien entwickelt. 


\section{INTRODUCTION}

"Admitting he was not too old to be surprised, Jack Welch, veteran chairman of General Electric and mastermind of its intended merger with Honeywell, stomped away from Brussels on June $14^{\text {th }}$, saying that the European Commission's conditions for allowing the deal were so tough that they would fatally undermine it. But should he have been surprised? ... For its part, GE was slow initially to grasp that the commission would be a lot tougher than its American counterparts.” (The Economist, 2001a: 73)

The majority of domestic mergers and acquisitions pass the antitrust review process with only nominal government perusal; however, antitrust authorities can and do launch extensive merger investigations (for raw evidence see OECD, 1998). Such investigations may negatively impact firms by delaying the onset of the intended merger, and may further negatively impact firms if they lead to merger restrictions or outright merger prevention (Pittman, 1977). Thus from a managerial perspective, the antitrust process exhibits substantial holdup potential (Post, Lawrence \& Weber, 1999). Managers are accustomed to antitrust holdup from home-nation antitrust authorities; however, two global trends from the last two decades have increased the likelihood of foreign-nation antitrust holdup. First, a number of nations have strengthened their antitrust regulations in order to secure the benefits of deregulation (Boner \& Krueger, 1991). Second, domestic mergers increasingly involve international implications that affect market outcomes in foreign markets (Melamed, 2000). Consequently, managers are increasingly uncertain regarding the source (home-based or foreign-based) of antitrust holdup for merger reviews (The Economist, 2001b).

My purpose is to develop a conceptual framework for predicting the source of antitrust holdup for domestic mergers with international effects. Explaining what drives alternation between home-based and foreign-based antitrust holdup merits attention as the above mentioned global trends-enhanced domestic antitrust policies and growing international effects of domestic mergers-show no signs of abating; hence, an increasing amount of uncertainty exists over the source of antitrust holdup for domestic mergers. I base the conceptual framework on a new sub-literature within industrial organization (IO) that 
considers domestic mergers in an open economy (Barros \& Cabral, 1994; Levinsohn, 1997; Sorgard, 1997; Head \& Ries, 1997; Yano, 2001; Zhang \& Chen, 2002) and the institutional literature within international political economy (IPE) and political economy (see Lenway \& Murtha, 1994; Murtha \& Lenway, 1994; Hillman \& Keim, 1995 for how business scholars treat this literature).

Much of the prior management research on business-government interaction lies in the domain of corporate political strategy (CPS: e.g., Baysinger, 1984; Keim \& Zeithaml, 1986; Keim \& Baysinger, 1988; Lenway \& Rehbein, 1991; Schuler, 1996). Fundamental to the CPS perspective has been the contention that a two-way relationship exists between business and government: government impacts business, but business also impacts government (Epstein, 1969; Aplin \& Hegarty, 1980). Research in CPS has enhanced our understanding of the business-government interaction concerning a number of different public policies. Management scholars, however, have not focused on antitrust policy or on the businessgovernment interface concerning antitrust policy (Barney, 2001). This author found only two management studies—Hillman, Zardkoohi and Bierman (1999) and Clougherty (2003)—-that consider businesses' ability to politically shape antitrust outcomes; though admittedly, this omission is shared by other disciplines concerned with the business-government interface (McChesney \& Shughart, 1995). Yet, the dearth of management scholarship particularly surprises in light of the extensive management research on other merger dimensions: motives; stock-market reactions; top-management turnover; R\&D expenditures; and more (O’Shaughnessy \& Flanagan, 1998). Beyond filling a void in the management and CPS literatures with respect to antitrust holdup for domestic mergers in a cross-national setting, this analysis makes two additional contributions to the CPS literature: 1) by specifically incorporating cross-national institutional variation for antitrust policy in to the conceptual framework; 2) by enhancing the rigor of CPS scholarship. 
First, management scholars writing from the CPS (e.g., Hillman \& Keim, 1995) and International Business (e.g., Boddewyn \& Brewer, 1994) traditions have been calling for researchers to note that the business-government interface is altered by different institutional contexts. For instance, Dunning (1997) observes that a number of different contexts exist across nations due to historical, cultural and political artifacts. Accordingly, management scholarship (e.g., Hillman \& Hitt, 1999; Henisz \& Zelner, 2001; Delios \& Henisz, 2003) has increasingly recognized that political institutions play an important mediating role in the business-government interface. Antitrust policy also indicates cross-national variation in its institutional context (Scherer, 1996). While the analysis here begins by assuming crossnational homogeneity in antitrust institutions in order to identify the primer driver of holdup source, later sections allow for cross-national institutional variation. Specifically, I identify three dimensions — institutional mission, institutional capability, and institutional autonomythat are critical to antitrust policy and alter the primary causal forces behind the holdup source. In short, this analysis responds to the call within CPS to factor institutional variation in the business-government interface.

Second, a number of management scholars (Epstein, 1980; Mitnick, 1993; Vogel, 1996) have expressed concern regarding the lack of rigor in the CPS literature. The supporting role of the IO and IPE literatures in this analysis yields a systematic approach that enhances analytical-rigor. The IO literature helps uncover the primary economic drivers behind antitrustholdup source and formulate testable propositions that rest on structural foundations. The IPE literature helps untangle the variation found in the cross-national institutional setting for antitrust. In short, this analysis responds to the call within CPS to enhance analytical-rigor with respect to the business-government interface.

Developing a framework to illuminate the business-government interface concerning home and foreign antitrust holdup requires five specific steps-steps upon which the organization of the paper follows. First, I define the concept of antitrust holdup and consider its 
managerial relevance. Second, I build on the IO literature to identify the primary causal force behind when home or foreign antitrust authorities are the more likely holdup source for a domestic merger with international effects. Third, using cross-national (27 antitrust jurisdictions) and pan-time (1992-2000) data, I present empirical tests supportive of an industry's global competitiveness driving the source of antitrust holdup. Fourth, I invoke the literature on political economic institutions in order to factor variation in the cross-national institutional environment for antitrust, and find institutional characteristics to mediate the impact of the primary causal force. Fifth, using the insights captured by the above steps, I prescribe normative propositions for the optimal political strategy of merging firms. Figure 1 illustrates the conceptual framework, specific contribution areas and accordant propositions.

Insert Figure 1 about here

\section{ANTITRUST HOLDUP: DEFINITION \& MANAGERIAL RELEVANCE}

Prior to delving further into the relevant theory and generating propositions regarding the business-government interface for merger reviews, it behooves us to clarify the concept of antitrust holdup. Antitrust hold-up plays a fundamental role in the analysis, as the paper holds throughout that antitrust scrutiny (whether home or foreign) remains a threat to merging firms. Consequently, I define antitrust holdup in this context to be any action taken by an antitrust authority that reduces or delays the intended benefits of a proposed merger. The discussion below will elaborate on the construct and clearly state the managerial relevance (i.e., the bottom-line) of being able to predict the source of antitrust scrutiny for domestic merger activity.

Despite variation in antitrust policy structures across nations (Scherer, 1996), one can generate a 'typical' antitrust process by which the majority of nations conform. First, each 
nation experiences so many proposed domestic mergers over a certain period. Of these proposed mergers, a large number will customarily require reporting to antitrust authorities. While the great majority of reported mergers pass the antitrust review process with virtually no antitrust perusal, certain mergers will raise antitrust concerns and be subject to further investigation. In the US, approximately 5\% of mergers reach this scrutiny level (OECD, 1998; U.S. DOJ, 1998). After a more detailed investigation, the antitrust authority can take a number of actions: accept as proposed; accept with provisions for monitoring and/or with stipulations on post-merger competitive tactics; accept with requirements for asset divestment; or prevention. Note that many mergers become dissolved when merging parties find their venture meriting higher-and-higher levels of scrutiny; hence, dissolved mergers also represent antitrust holdup. Figure 2 illustrates the indexical nature of antitrust scrutiny. Accordingly, we can operationalize our earlier definition of antitrust holdup by noting that levels of antitrust scrutiny that involve investigations, monitoring and/or competitive curbs, dissolved mergers, asset divestments and preventions represent antitrust holdup. Note then that antitrust holdup is more than a dichotomous construct (where a merger is either approved or rejected) as higher levels of scrutiny reflect higher degrees of holdup, and higher degrees of holdup represent enhanced threats to the intended strategy of merging firms.

Insert Figure 2 about here

The holdup threat traditionally originates from home antitrust authorities, but increasingly originates from foreign antitrust authorities. Some readers may question the ability of foreign-nation antitrust authorities to impact domestic mergers in other nations; yet, foreign authorities have a few means to counteract these mergers. First, when merging firms have international operations, foreign authorities can prevent or curtail the merger with respect to those operations. For instance, Coca Cola’s acquisition of Cadbury-Schweppes' soft-drink 
business was curtailed by various national antitrust authorities objecting to the integration of bottling plants and distribution networks within their national borders (OECD, 1998). Second, if a bilateral treaty exists between two nations for antitrust issues, then foreign authorities can potentially block the merger via the bilateral procedure (Campbell \& Trebilcock, 1997). Third, many authorities (US and EU in particular) apply antitrust laws outside their territory (Trebilcock, 1996).

Providing a framework that reduces uncertainty over the source of antitrust holdup consequently yields a number of benefits for merging parties. First, prior knowledge regarding which jurisdictions are likely to present higher degrees of antitrust holdup helps acquiring firms make optimal target choices: i.e., avoid targets with significant operations in nations likely to engage in holdup. Second, prior knowledge on the degree of antitrust holdup might help with time-dependent mergers (where a quick response to a rival is necessary or stockmarket valuation changes can reduce merger value), as higher degrees of antitrust holdup reflect enhanced time and effort in obtaining merger approval. Third, prior knowledge on the likely source of antitrust holdup can help top-management direct limited political resources where most useful, and avoid engaging in wasteful—if not dangerous due to credibility and legitimacy concerns (Epstein, 1969; Yoffie, 1987)—lobbying of antitrust authorities predisposed to clearing a merger.

\section{PRIMARY CAUSAL FORCE BEHIND ANTITRUST HOLDUP SOURCE}

The management literature has certainly moved beyond the traditional one-way approach to business-government interaction, yet this section adopts a one-way perspective: with causation strictly moving from government to business (Epstein, 1969, 1980; Boddewyn \& Brewer, 1994). The main reason behind invoking a simplistic one-way perspective is that scholars tend to argue that antitrust conforms rather well to a one-way perspective relative to other public policies: i.e., public interest rationales tend to dominate private interest rationales 
in explaining antitrust outcomes (Rubin, 1995). ${ }^{1}$ Even George Stigler-renown for arguing that private, as opposed to public, interest lay behind regulatory policy—considered antitrust to be public interest driven (McChesney and Shughart, 1995). Simply put, the realm of antitrust policy is closer to the one-way ideal than most public policies; though, the one-way assumption is relaxed in subsequent sections in order to factor the marginal impact which merging-firms’ political pressure might have.

A one-way (or public interest analysis) of the business-government interface for antitrust accordingly requires factoring the national welfare implications; hence, I draw on the IO literature. Such a supporting role may appear out-of-step with management's continued move away from an embrace of IO inspired analysis (Conner, 1991; Rumelt, Teece \& Schendel, 1991; Priem \& Butler, 2001); yet, the economic perspective is pivotal since it has substantially impacted antitrust practice (Kovacic, 1992; Kovacic \& Shapiro, 2000; Barney, 2001). A voluminous literature (e.g., Williamson, 1968; Fisher, 1987; White, 1987; Farrell \& Shapiro, 1990) exists concerning the welfare effect of mergers involving only domestic competitive implications: i.e., domestic merger activity in a closed economy. Yet this analysis attempts to factor considerations beyond the traditional domestic effects (may they be marketpower or efficiency-gains based) involved with domestic merger reviews. In short, this analysis attempts to factor the marginal impact of international considerations on domestic merger reviews.

Fortunately, a new literature stream (Barros \& Cabral, 1994; Levinsohn, 1997; Sorgard, 1997; Head \& Ries, 1997; Yano, 2001; Zhang \& Chen, 2002) within IO exists that considers domestic mergers involving both domestic and international competitive implications: i.e., domestic merger activity in an open-economy setting. The sub-literature (hereafter referred to

\footnotetext{
${ }^{1}$ By private interest, I refer to the large cross-disciplinary literature that looks within society to political actor groups in order to explain public policy outcomes. Bentley (1908), Truman (1951), and Downs (1957)—all helped spawn this research tradition. By public interest, I refer to the large cross-disciplinary literature that looks within government institutions in order to explain public policy outcomes. Schumpeter (1950), Kalt \& Zupan (1984) and Evans (1995) —all fit within this research tradition. The two research traditions_-private interest and
} 
as open-economy IO) sets the basis for this analysis by generating consistent predictions on how an industry's global competitiveness — reflected by trade-balance-mediates a domestic merger's impact on home-nation and foreign-nation welfare. ${ }^{2}$ The important point to underscore regarding the open-economy IO literature is that it exhibits a great deal of variation with regard to merger criterion, evaluation techniques, modeling techniques and critical assumptions; nevertheless, the studies all converge on the relevant impact of industry tradebalance:

- Impact of Net-Exporter Status: Nations with a net-exporter profile in a particular industry find their national welfare enhanced when lax merger policy is practiced.

- Impact of Net-Importer Status: Nations with a net-importer profile in a particular industry find their national welfare enhanced when strict merger policy is practiced.

This convergence becomes more powerful when one recognizes that economic modeling is famous for yielding a variety of potential market solutions.

The analysis to this point has remained at a rather abstract level due to the technical nature and varying methods used by the different open-economy IO studies. However, the basic intuition behind the literature stream can be conveyed after setting two of the literature's underlining dynamics: 1) national antitrust authorities do not factor the welfare of foreign producers and consumers; 2) the basic producer-gain/consumer-loss tradeoff informs antitrust decisions.

First, the open-economy IO literature exploits the fact that national antitrust authorities are not charged with protecting the welfare of foreign producers or consumers. Accordingly, the national welfare effect of a domestic merger for a home-nation consists of the change in merging home firms’ profits, the change in non-merging home firms’ profits, and the change in

\footnotetext{
public interest - span a number of literatures including: corporate political strategy, political economy of regulation, public choice, and IPE.

2 The 'Global Competitiveness of an Industry' refers to the world competitiveness of a national industry: e.g., Japan is globally competitive in auto manufacturing. The underlying assumption is that the more an industry is a net-exporter the more competitive it is, and the more it is a net-importer the less competitive it is. The globalcompetitiveness conceptualization could be extended to include sales by foreign affiliates and subsidiaries, since foreign direct investment accounts for a large amount of a national industry's foreign sales. Yet in order to keep the analytical framework tractable, this simple extension is not implemented here.
} 
home consumer surplus. Similarly, the national welfare effect of a domestic merger with international-competitive-effects on a foreign-nation consists of the change in foreign firms' profits, and the change in foreign consumer surplus.

Second, the sub-literature on domestic mergers in an open economy recognizes that mergers generally result in higher consumer prices--i.e., reduced consumer-surplus. In part, this owes to the fact that most domestic mergers create no synergies (see Sirower, 1997 and Meuller, 1997 for reviews of this sobering literature). While some mergers do, nevertheless, involve synergies, Farrel and Shapirio (1990) show that only substantial synergies result in lower prices: substantial synergies support a merger’s efficiency effect (leading to lower prices) dominating the decreased-competition effect (leading to higher prices). Consequently, the great majority of mergers (lacking the necessary significant synergies) lead to higher consumer prices. For this reason, the literature and practice on merger-reviews focuses on the tradeoff between producer-gains and consumer-losses (Levinsohn, 1997).

With the above dynamics as a backdrop, the basic intuition behind the open-economy IO literature follows: national antitrust authorities find that the tradeoff (between producergains and consumer-losses) vanishes when a sector is characterized as a net-exporter. Domestic merger activity in more export-oriented sectors tends to result in the consumer-losses being incurred by foreign-consumers and the producer-gains being incurred by home-producers. Accordingly, the more export-oriented the sector the more the search for producer-gains drives merger policy (Levinsohn, 1997). The following four scenarios provide additional specificity on how trade-balance impacts home and foreign nation welfare. The four scenarios yield two propositions that help build the systematic conditions for home and foreign antitrust holdup.

First, consider the case of a home antitrust authority's need to evaluate a domestic merger in an industry structure characterized by net-exporter status. In this case, the merger is likely to be approved by the home antitrust authority because home producer-gains outweigh home consumer-losses when home producers earn substantial gains in foreign markets. Key is 
that home firms find an improved competitive position in both home and foreign markets, as their profit gains are not restricted to domestic markets. Since home consumer-losses are relatively insubstantial, the merger likely sails through the antitrust process without major hurdles.

Second, consider the case of a foreign antitrust authority's need to evaluate a domestic merger in another nation when the foreign nation is a net-importer in that industry: similar to the first scenario, except we take the alternative perspective of the foreign antitrust authority. In this case, the merger is likely to be held up by the foreign antitrust authority as it reduces foreign-nation welfare. Key is that foreign firms may experience enhanced producer surplus (unless the merger involves significant synergies), but these gains are restricted to the foreign domestic market. Foreign firms simply do not reap substantial profit gains in other markets; consequently, the minimal gains to foreign firms are unlikely to outweigh foreign consumerlosses. The negative impact on foreign-nation welfare suggests that the merger faces antitrust hurdles in the foreign market. The first two scenarios can be summed up by a representative proposition:

Proposition 1a: Domestic mergers occurring in net-exporter industries less likely face high degrees of home antitrust holdup, and more likely face high degrees of foreign antitrust holdup-particularly from foreign net-importer nations.

The previously noted case of the GE/Honeywell merger illustrates proposition 1a well. The US can be considered a net-exporter and the EU a net-importer in the bilateral EU-US trade in aerospace products (European Commission, 2000). Per the above theoretical contentions, it was the EU—not the US—which raised antitrust objections to this all-American merger. Observers report that the EU was particularly concerned about GE's post-merger ability to bundle its aerospace products, and adversely affect European companies that were GE customers (The Economist, 2001a). The proposed acquisition of BOC by 
AirProducts/AirLiquide (an all-European merger) indicates an additional example of the above proposition; though, the incentives and positions are reversed for US and EU antitrust authorities. The EU can be considered a net-exporter and the US a net-importer in the bilateral EU-US trade in industrial gases (The Economist, 1999). And per the above theoretical contentions, it was the US—not the EU—which raised antitrust objections to this all-European merger (The Economist, 2001b).

As a third scenario, consider the case of a home antitrust authority's evaluation of a domestic merger in an industry structure characterized by net-importer status. In this case, the merger is more likely to be held up by home antitrust authorities because of a negative impact on home-nation welfare. Key is that any domestic profit gains are split between home and foreign firms; plus, home firms do not reap substantial international profits when they are netimporters. Consequently, home consumer-losses likely outweigh the minimal producer-gains of home firms. The negative impact on home-nation welfare suggests that the home antitrust authority will hold up the merger.

Fourth, consider the case of a foreign antitrust authority's need to evaluate a domestic merger occurring in another nation when the foreign nation is a net-exporter in that industry: similar to the third scenario except we take the alternative perspective of the foreign antitrust authority. In this case, the merger is unlikely to be held up by foreign authorities because the merger positively impacts foreign-nation welfare. Such a positive impact owes to the substantial profit gains by foreign firms in the merger's home-market. Foreign firm profit gains should outweigh minimal foreign consumer-losses - in fact, if home producers are noncompetitors in the foreign market, then foreign consumers may not even suffer losses. The positive impact on foreign-nation welfare suggests that foreign antitrust authorities will be little concerned by the merger. The third and fourth scenarios can be summed up by a representative proposition: 
Proposition 1b: Domestic mergers occurring in net-importer industries more likely face high degrees of home antitrust holdup and less likely face high degrees of foreign antitrust holdup-particularly from foreign net-exporter nations.

The case of EU antitrust policy for the television and media industries illustrates proposition 1b well. The EU can be considered a net-importer and the US a net-exporter in the bilateral EU-US trade for television and media services (European Commission, 2000). European firms noted the need to respond to increasingly strong and integrated US competitors as a principal motive behind seeking European mergers (Bouwman, 1995). Per the above theoretical contentions, the EU Commission remained steadfast in its commitment to sound antitrust policy by rejecting six proposed mergers over the 1994-1998 period; further, these allEuropean mergers elicited no concerns from US antitrust authorities (The Economist, 2000).

In sum, the global competitiveness of a national industry (manifested by trade balance) plays a pivotal role in determining whether antitrust holdup is more likely to come from home or foreign antitrust authorities. Domestic mergers occurring in net-exporter nations more likely find antitrust holdup coming from foreign authorities than from home authorities. Conversely, domestic mergers occurring in net-importer nations more likely find antitrust holdup coming from home authorities than from foreign authorities. Figure 1 illustrates the commencing position that the one-way propositions take in the conceptual framework. The managerial implications of the above are quite clear: expect foreign antitrust holdup when a domestic merger is in a net-exporter industry; and expect home antitrust holdup when a domestic merger is in a net-importer industry.

\section{EXPLORATORY EMPIRICAL TESTS}

As already noted, the foundations behind propositions' 1a \& 1b are purely conceptual, as the open-economy IO literature lacks empirical testing of the theoretical conformity. This 
section responds to this deficiency in the literature by conducting some exploratory empirical tests to gather whether larger trade-balances lead to more permissive merger policies. The immediate motivation behind including the tests is to provide some hard evidence as to whether the primal causal force (trade-balance) behind the proposed conceptual framework entails empirical validity. Note that propositions $1 \mathrm{a}$ and $1 \mathrm{~b}$ could be summarized as follows: the larger the trade-balance, the more it is in the public interest for an antitrust authority to be lax with regard to both home and foreign domestic mergers. Consequently, if net-exporter antitrust jurisdictions are generally more lax with regard to merger activity than net-importer jurisdictions, then supportive evidence exists for trade-balance driving the source of antitrust holdup.

This empirical effort should be characterized as a second-best approach, as it suffers from some data-coverage deficiencies. More specific industry-by-industry data—or even better, firm-level data on the source of antitrust holdup-would better test the primary contention; yet, such sectoral and firm level data is lacking. As Horn and Levinsohn (2001) note, the state of cross-national data on antirust policy is rather primitive. Accordingly, the national-level data employed here is the best available means to test whether the main dynamic (trade balance) behind the conceptual framework entails empirical validity. It should be reiterated that this effort represents the first—-to this author's knowledge-empirical work that attempts to estimate whether national merger policies are subject to international competitive effects; tolerance of data-set deficiencies may then be in order.

The data consist of annual measures of merger policies for 27 jurisdictions over the 1992-2000 period. $^{3}$ The dependent variable should capture the annual level of regulatory scrutiny (i.e., antitrust holdup) with respect to merger activity for a particular antitrust

\footnotetext{
${ }^{3}$ The 27 antitrust jurisdictions include the following: Australia, Austria, Belgium, Canada, Czech Republic, Finland, France, Germany, Greece, Hungary, Ireland, Italy, Mexico, Netherlands, New Zealand, Norway, Poland, Portugal, South Korea, Slovakia, Spain, Sweden, Switzerland, Turkey, United Kingdom, United States and the European Union. I include the EU despite it being a regional—not a national—government. Unreported regressions, that were similar to those reported but excluded EU data, showed no discrepancy relative to the
} 
jurisdiction. Raw data from the OECD (1992-2000) on the annual merger policies of member nations allows the compilation of a measure that directly corresponds to the earlier definition of antitrust holdup: the number of annual antitrust actions-where actions refer to mergers that are monitored, restructured, prevented or abandoned—taken by an authority. Accordingly, the variable reflects an annual account of the antitrust actions — acts of antitrust holdup — taken by a particular jurisdiction (hereafter referred to as Antitrust Scrutiny).

In order to test the validity of propositions $1 \mathrm{a} \& 1 \mathrm{~b}$, the main explanatory variable must capture whether the nation is an overall exporter or importer of traded goods. Data from the World Bank's 'World Development Indicators' (WDI) series allows calculating trade balance (exports - imports) as a percentage of GDP; thus, indicating whether a nation is a net-exporter and how much weight the trade profile involves with respect to the domestic economy (hereafter referred to as Trade-Balance). Expect Trade-Balance to negatively impact AntitrustScrutiny, as net-exporter nations find it beneficial to be relatively lax with regard to merger activity.

Further, additional drivers of antitrust scrutiny must be factored in order to make sound causal inferences on the impact of trade-balance. Boner and Krueger's (1991) analysis of crossnational antitrust policies for the World Bank assists in identifying the appropriate control variables, as it specifies the main drivers of variation in cross-national merger policies. Boner and Krueger note that wealthy, large and deregulated are the qualities that encourage the adoption of sound national antitrust policies.

First, wealthy nations tend to have an incentive and the means to adopt stringent antitrust policies. Relatively wealthy nations can afford the expertise of well-trained lawyers and economists: necessary commodities to be able to engage in active antitrust policies. Further, antitrust could be considered a luxury item in the menu of public policies: economic development and industrialization clearly take a priority. For instance, India has long had 
antitrust policy on the books, but has failed to enforce these rules due to the pressing need for public polices that address basic economic development (Bare Act, 1999). Accordingly, data from the World Bank's WDI series on Gross Domestic Product measured under purchasing power parity terms (hereafter referred to as GDP) was included as a control variable.

Second, larger nations are thought to have an incentive to adopt stringent antitrust policies. Since relatively small nations are subject to large trade effects (i.e., trade makes up a greater percentage of their economy), trade policy acts as a substitute for antitrust policy in these nations. For instance, the Netherlands has long refrained from establishing a rigorous antitrust policy as the open nature of the economy precluded domestic firms from engaging in substantial anti-competitive activities. Yet relatively large nations can not look to trade policy to bail them out with regard to domestic anti-competitive behavior. Unsurprisingly the US, Germany and the EU (relatively large jurisdictions) are regarded as having the most stringent antitrust policies over the last two decades. In short, large nations face particularly strong incentives to ensure the welfare gains of adequate domestic competition. Accordingly, the World Bank's WDI series provides data on the population of the antitrust jurisdiction (hereafter referred to as Population) that was included as a control variable.

Third, the less regulated a national economy the more a nation faces an incentive to adopt stringent antitrust policies. For example, most of the nations that deregulated their economies over the last twenty years followed suit with beefed-up antitrust polices. Enhanced antitrust policies were installed to secure the benefits of deregulation; otherwise, the welfare gains from deregulation may have been dissipated by merger activity or other anti-competitive practices. Accordingly, the number of national firms listed on a stock exchange is used to proxy the degree to which market forces are adopted by a particular nation (hereafter referred to as Deregulation). Note that tax revenue as a percentage of GDP was also used to proxy 
deregulation and yielded similar results; however, the data coverage of this variable was far more limited than that of listed firms.

Properly analyzing the data requires the consideration of a few econometric issues: functional form; choice between fixed and random effects; and the appropriateness of period effects. First, I assume that the explanatory variables involve a linear relationship with the dependent variable; however, the explanatory variables may take a different functional form. In order to check on the robustness of the results, the natural log is introduced for those variables (GDP, Population, and Deregulation) that exclude negative and zero values - values which prevent taking the natural log. Second, a random-effects regression was chosen over fixedeffects due to the relatively low degrees of freedom (only 158 observations) available for the tests. Greene (1990) points out that fixed-effects involve a large loss of degrees of freedom; hence, yielding practical merits for the choice of random-effects when observations are limited. Further, random-effects regressions allow a relationship between panel effects while fixedeffects methods do not. Nevertheless, unreported fixed-effects results support the reported random-effects results. Third, gradual changes - e.g., increased adoption of stringent antitrust policies by smaller nations at the urging of the EU and US-have occurred in the crossnational environment for antitrust over the 1992-2000 period. These changes create timespecific data trends that affect causal inferences and call for the addition of period-effects.

The three reported regression equations in Table 1 take the above econometric concerns into account. Regression 1 reports a simple linear OLS regression; Regression 2 reports a linear-logarithmic OLS regression where three explanatory variables - GDP, Population, and Deregulation—-take the natural log form; and Regression 3 reports a random-and-period effects specification. Since Regression 3 is the most econometrically comprehensive of the three regression models, it is represented as follows:

Antitrust-Holdupit $=\mathbf{b}_{0}+\mathbf{b}_{1} *$ Trade-Balanceit $+\mathbf{b}_{2} * G_{\text {GP }}$ it $+\mathbf{b}_{2} *$ Population $_{i t}+$ $\mathbf{b}_{4} *$ Deregulation $_{\mathbf{i t}}+\varepsilon_{\mathbf{i t}}+\mathbf{u}_{\mathbf{i}}+\mathbf{w}_{\mathbf{t}}$ 
where $\mathrm{i}$ indexes the 27 antitrust jurisdictions, $\mathrm{t}$ indexes time (year), $\mathrm{u}_{\mathrm{i}}$ represents the random panel-effect, and $\mathrm{w}_{\mathrm{t}}$ captures the period-effect.

Table 1 reports the regression results for the three regression models-all three models generally report significant results that conform to expectation. Further, the models appear to yield consistent results across the three separate regressions (the only difference being the lack of significance for Deregulation in Regression \#2); accordingly, the following analysis concentrates on Regression \#3 since it is the most econometrically comprehensive and the results are similar to the other two regressions. Regression \#3 reports a random-and-period effects estimation where all of the coefficient estimates (with the exception of Population) conform to expectation; hence, more-wealthy, less-populated, and deregulated antitrust jurisdicitions tend to experience more antitrust scrutiny with respect to merger activity. Moreover, our chief concern is the Trade-Balance variable, as this tests whether net-exporter nations are lax with regard to merger activity. The coefficient estimate $(-0.201)$ for TradeBalance is negative as expected and significant at the 5\%-level. Beyond statistical significance, the coefficient estimate's economic significance suggests that if trade-balance were to increase from $0 \%$ to $5 \%$ of GDP then that nation would experience one less antitrust action per year. Consequently, net-exporter nations appear to treat merger activity more leniently than do netimporter nations: the principal dynamic behind the proposed conceptual framework does appear to be empirically valid.

It is worth reiterating now that the main aim of the paper remains to set out a conceptual framework for predicting the source of antitrust holdup for domestic mergers under cross-national institutional variation, and to yield corporate political strategy implications. In the context of this analysis, the empirical results allow us to feel more confident about the underpinnings of the conceptual framework. Yet, the empirical tests do represent a first empirical effort to gather whether nations with high trade-balances treat merger reviews with more leniency; and as such, the results involve relevance beyond the current context. First, the 
empirical results support the theoretical conformity in the open-economy IO literature that netexporter profiles favor more lenient merger policies. Second, the empirical results suggest that the harmonization of cross-national merger policies (discussed in the current round of WTO talks) may be merited, as such harmonization could curb net-exporter nations from practicing beggar-thy-neighbor merger policies.

\section{ADDING CROSS-NATIONAL INSTITUTIONAL VARIATION}

The analysis until this point has implicitly assumed cross-national homogeneity in antitrust institutions and policies. Cross-national variation in antitrust laws and enforcement has certainly been reduced over the last two decades due to a number of causes: the need to secure the benefits of domestic deregulation (Boner and Krueger, 1991); globalization pressures (Ostry, 1997; Clougherty, 2001); and international cooperation and harmonization efforts (Graham \& Warner, 1994; Scherer, 1996; Graham \& Richardson, 1997). Nations, however, have yet to converge on a homogeneous antitrust policy. Scherer (1996: 5) indicates heterogeneity in national antitrust policies when he states "huge differences remain between nations in both the substance and philosophical foundations of national laws”.

A number of management scholars (e.g., Boddewyn \& Brewer, 1994; Khanna \& Rivkin, 2001) note the importance of factoring cross-national institutional variation. Lenway \& Murtha (1994), Murtha \& Lenway (1994), and Hillman \& Keim (1995)—all prod scholars by example to understand the institutional context through which the business-government interface takes place, because variation in the institutional context often explains variation in the business-government interface. This section recognizes cross-national variation in terms of the actual institutional conditions for antitrust policy, and identifies three critical dimensions: institutional mission, institutional capability and institutional autonomy. The three institutional dimensions might remind readers versed in the strategy literature of the foundational role played by a mission statement (institutional mission), internal analysis (institutional 
capability), and external analysis (institutional autonomy) in the top-down strategy making process (Hill \& Jones, 2004). Most importantly, relaxing the assumption of cross-national institutional homogeneity necessarily alters the previously proffered one-way propositions: P1a and P1b.

A number of different political traditions exist that broadly consider the impact of institutions on the business-government interface (e.g. North 1981, 1990). This analysis, however, rests on the work in the IPE literature; thus, certain qualities of an IPE approach to institutions should be made explicit. First, IPE scholars tend to broadly define institutions in light of the inability to engage in simple theorizing when it comes to institutional analysis: e.g., Goldstein and Keohane state that political institutions are "administrative agencies, laws, norms and operating procedures” (p. 20). Despite the broad definitional approach, IPE analysis of institutions tends to be rather specific in aim or purpose: focusing on the elements of political institutions that are fundamental to the specific public policy being analyzed. Accordingly in the context of this analysis, 'institution' refers to the specific political institutions (namely antitrust agencies) and the incumbent mission, capability and autonomy of these institutions. Further, the qualities and characteristics of antitrust institutions are considered exogenous for this analysis. While institutional characteristics are certainly subject to primal causal forces and the interests of other political institutions (e.g., the executive office and the legislature--see Vachris 1996 for a literature review), change in the characteristics of political institutions is a long-run phenomenon (Milner \& Keohane, 1996). In sum, 'institution' should be understood here as referring to the political institutions directly in charge of antitrust policy that are exogenously determined in the short-term.

\section{Institutional Mission}

An institution's mission—an articulation of vision, values and goals_-plays a primary role in the business-government interface because it sheds light on the priorities and direction 
of an antitrust authority. Gathering institutional direction remains imperative because different antitrust authorities will manifest different institutional objectives (Doern, 1996). Every antitrust agency will certainly state that safeguarding competition is a primary goal; yet, significant variation remains in how such a broad goal is operationalized. This observation is in line with IPE research on the power of ideas and embedding of ideas within institutions (see Goldstein and Keohane, 1993 for a review). Ideas have causal force once they become entwined with interests; hence, ideas (reflected by institutional mission) have real power in explaining public policy outcomes. For this study, two specific ideological elements of an antitrust agency's mission appear appropriate: 1) the degree to which an antitrust authority commits to competition issues; 2) the degree to which an antitrust authority factors international-competitive-effects.

First, if all antitrust institutions had perfect knowledge and were bent on promoting competition, then understanding the institutional context would be relatively unimportant. Many antitrust agencies, however, do more than strictly promote competition. Boner and Krueger (1991) cite a number of non-competition goals--industrial, employment and regional policy--that antitrust agencies are often charged with promoting. Akin to the difficulty of predicting firm-behavior when firm objectives involve multiple goals (Drucker, 1974), it is far more difficult to predict the actions of a government agency charged with multiple policy goals (Wall \& Eisenbeis, 2000). In line with this contention, Clougherty (2001) empirically supports national commitments to antitrust principles as reducing variation in domestic merger policy. Antitrust agencies with multiple policy goals can't focus strictly on the producergains/consumer-loss tradeoff; hence, the national welfare incentives formulated in the first section have less prediction power when antitrust authorities are charged with multiple policy tasks.

The cross-national environment indicates a variety of actual antitrust goals. Neumann (1990) notes that industrial policy increasingly manifests itself in antitrust policy decisions. 
France, for example, often uses antitrust policy as a vehicle for other public policies: the OECD (1998) report on cross-national antitrust activity is replete with examples where the French government openly notes the industrial and/or employment policy rationales behind merger decisions. Even US antitrust policy allows a failing-firm-defense where insolvent firms can engage in anti-competitive mergers (U.S. DOJ, 1998). Consequently, it is not difficult to imagine a domestic merger in a net-importer industry being supported by a government on industrial policy grounds. Recent discussions concerning US steel industry consolidation—an industrial sector far from internationally competitive-provide a good example where competition issues might be relegated to secondary importance (The Economist, 2001c). Accordingly, the mainstream economics approach to public interest (the national welfare focus underlining the one-way propositions) is not universally adopted.

Second, the main claim of the one-way analysis — trade balance determines whether a domestic merger faces home or foreign antitrust holdup-assumes that internationalcompetitive-effects will be considered in the merger review process. As noted above, however, antitrust institutions can’t universally be reduced to entities strictly maximizing national welfare. Even antitrust policy (the most celebrated of public policies from an economic perspective) often falls short of the public interest ideal (Long, Schramm \& Tollison, 1973; Eckbo \& Wier, 1985; Bittlingmayer, 1985; Yandle, 1995). Despite the potential for an industry's global competitiveness to alter the impact of a domestic merger on home and foreign nation welfare, the relevant antitrust authorities may simply ignore international implications; i.e., international-competitive-effects may not be part of an antitrust agency's mission. A great deal of IPE scholarship (e.g., Goldstein, 1989; Goldstein \& Lenway, 1989; Goldstein, 1993) suggests that government institutions are prone to inertia. Further, Waldman (1985) argues that antitrust has been overwhelmingly domestic in its nature, while Boner and Krueger (1991) note that antitrust has been largely employed to protect domestic competition. Accordingly, antitrust agencies might resist factoring international-competitive-effects; thus, neutralizing the 
relevance of the analyzed welfare incentives. In essence, the gap must be filled between the normative prescriptions generated by the new literature on domestic mergers in an open economy and the positive decisions regarding actual mergers.

While variation exists across nations on the degree to which international-competitiveeffects impact antitrust decisions, the cross-national institutional environment appears conducive to factoring international-competitive-effects. Levinsohn (1997) notes that it is conspicuous to find a number of nations (e.g., Phillipines, Ireland, Germany, Greece, Switzerland) taking starkly different approaches to domestic antitrust (where they employ sound policy) and international antitrust (where they employ lax policy). For example, Germany takes a rather strict approach to domestic antitrust issues, but a more relaxed approach to export industries: cartelization is even permitted for such industries (Trebilcock, 1996). Another interesting case is Japan where MITI routinely grants antitrust exemptions and cartel status with little moderating pressure from antitrust officials; further, foreign firms are given no official status in Japanese antitrust deliberations (Sanekata \& Wilks, 1996; Tilton, 1996). All of the above nations appear to whole-heartedly factor international-competitiveeffects. A number of antitrust authorities take a more subtle approach to factoring international-competitive-effects: Spain, France, Netherlands, Sweden, Belgium and the EUall focus their merger reviews on the tradeoff between producer and consumer surplus, yet specifically note that producer gains from exports are part of this tradeoff (Levinsohn, 1997). Canada and the UK exhibit further examples of how international-competitive-effects can be institutionalized, as both authorities are charged with expanding national participation in world markets (Competition Bureau, 1991; Doern, 1996). Even the US-the paragon of strict antitrust policy—allows cartelization for export purposes under the Webb-Pomerene Act (U.S. GAO, 1973). Further, Kovacic and Shapiro (2000)—respectively an esteemed legal and economic scholar on antitrust issues—note that declining economic productivity partly drove the lax US antitrust policy of the 1980's. Accordingly, the various antitrust institutional 
environments (particularly home antitrust institutions) appear amenable to factoring the international effects of domestic mergers.

Consequently, the institutional mission of an antitrust agency affects the businessgovernment interaction for antitrust policy. The more antitrust agencies are subject to competition goals and the greater their propensity to factor international-competitive-effects, the more trade-balance yields prediction power in explaining the source of antitrust holdup. The impact of institutional mission on the proffered one-way propositions is captured by the following proposition:

Proposition 2: The more committed an antitrust agency is to promoting competition issues and to considering international-competitive-effects, the more an industry's global competitiveness will be able to predict the likely source—home or foreign—of antitrust holdup.

Figure 1 illustrates where the effect of proposition 2 (institutional mission mediating the prediction power of the one-way propositions) falls within the greater conceptual framework.

\section{Institutional Capability}

An institution's capability-grounded in held resources and competencies-plays a primary role in the business-government interface because it gives some evidence as to what an antitrust agency can attain. An institutional mission might reflect all the 'right' objectives; yet, without the necessary resources and competencies such objectives can go unfulfilled. Influenced by the growing intersection of international management, strategy and national competitiveness concepts in a world where MNE's interact in multiple institutional contexts, Lenway and Murtha (1994) build a conceptual framework to factor what they call 'state organizational attributes'. Lenway and Murtha observe that cross-national differences in the strategic capabilities of states exist, and that these capabilities impact the success of homenation public-policy strategies in support of MNEs. The concept of state capability can also be 
narrowed to the realm of antitrust policy: three specific elements-legitimacy, budget and personnel—appear appropriate for a study of an antitrust agency's capability.

First, Lenway and Murtha (1994) note that domestic policy capability rests on the authority to make and enforce laws: i.e., public policies must be legitimately derived. Specific public policies necessitate legitimacy, for without legitimacy these policies will be ineffective. As an example, Indian antitrust laws have been on the books since 1969 (Bare Act, 1999), yet these laws have not been enforced: i.e., Indian antitrust policy lacks political legitimacy. ${ }^{4}$ Dutz and Vagliasindi (2000) note that implementation, as opposed to written laws, is critical for antitrust policy. Many developing and transition nations have only recently established antitrust policies, and a read through the OECD (1998) reports on annual antitrust policy suggests that the actions of new authorities are often restricted to establishing basic legitimacy: ensuring that businesses unaccustomed to antitrust policy actually report merger activities. Even antitrust agencies in developed nations often face legitimacy concerns: the Japanese Fair Trade Commission has faced serious legitimacy issues - it is generally considered to be proforeign and anti-Japanese-that have reduced its ability to practice sound antitrust policy (Sanekata \& Wilks, 1996; Tilton, 1996). As a contrast, US and German (the two nations with the longest antitrust traditions) antitrust policy receives a great deal of legitimacy (Boner \& Krueger, 1991). Consequently, the degree of political and societal support for antitrust fundamentally affects institutional capability: simply put, society must value its existence for otherwise no amount of resources will allow it to fulfill its mission.

Second, actual budgetary resources do, nevertheless, partly determine an agency’s capability. Schumpeter (1950) contends that budgetary support for bureaucrats is critical for sound public policy: bureaucrats, like entrepreneurs, are given a vaunted role in his political economic framework. More specifically, Kwoka (1999) suggests that antitrust budgets are the

\footnotetext{
${ }^{4}$ As anecdotal evidence of the lack of legitimacy for Indian antitrust, this author had a conversation with a student from India's top law school who did not know that antitrust policy existed as a concept nevertheless as an Indian law.
} 
principal means to measure national commitment to antitrust principles. Actual cross-national comparisons on budgetary support can be quite illuminating: for instance, France budgets some \$8 million per year for antitrust, while Germany budgets \$18 million per year (OECD, 1998). Such stark comparisons between nations elicit the importance of budgetary resources; yet, intra-nation comparisons are also telling. Kwoka (1999) shows that US antitrust enforcement budgets have been far outpaced over the last two decades by GDP growth, merger transactions and merger values. Consequently, even nations with long commitments to antitrust may not provide the extra resources required to vet an upswing in merger activity.

Third, budgetary capability is likely to correlate with the ability of government agencies to attract and keep qualified personnel. Management scholars (e.g., Hillman \& Keim, 1995; Hillman, Zardkoohi \& Bierman, 1999) have increasingly explored the implications of the quality and type of government personnel on the business-government interface. Antitrust agencies that lack adequate employee pay and quality will be incapable of fulfilling their missions. At a primary level, adequate antitrust requires expertise in economics and law. The OECD (1998) now tracks the number of lawyers and economists in the various national antitrust agencies in order to create transparency in cross-national technical expertise. Beyond the primary need for a qualified group of permanent economists and lawyers, antitrust agencies must often purchase competencies-akin to the 'buy' decisions undertaken by businesses. As an example, note the US Department of Justice's (DOJ) securing the services of David Boies, a high-profile trial lawyer, for the courtroom case against Microsoft (Auletta, 2001).

The ability of antitrust institutions to make sound and accurate decisions in what is already a difficult task depends on the legitimacy, budgetary resources and personnel competencies which agencies can muster. Institutional capability is a necessary condition for merging firms to face antitrust holdup: incapable agencies will simply not be able to fully engage in such complex activities. Net-importer nations may face incentives to block both 
home and foreign domestic mergers; yet, institutional capability mediates the ability to engage in significant antitrust holdup. Further, incapable institutions will be less subject to consistency and predictability in their antitrust rulings (Nilssen, 1997). ${ }^{5}$ The following proposition captures the impact of institutional capability on the proffered one-way propositions:

Proposition 3: The more capable—in terms of political legitimacy, budgetary support and personnel expertise - the antitrust agency, the more an industry's global competitiveness will be able to predict the likely source-home or foreign-of antitrust holdup.

Figure 1 illustrates where the effect of proposition 3 (institutional capability mediating the prediction power of the one-way propositions) falls within the greater conceptual framework.

\section{Institutional Autonomy}

An institution's autonomy-the degree to which it is immune from political pressures_-plays a primary role in the business-government interface, because it reflects how much an antitrust agency must take into account other political actors. A number of scholars (e.g., Schumpeter, 1950; Evans, 1995; Lenway \& Murtha, 1994) note that the ability of government institutions to act without regard to political interest groups or other government institutions critically effects public policy outcomes. The gist of the argument is that autonomous government institutions better enact public-interest driven policy, because they are immune to noisy pressure groups and territorial institutions. As an aside, the nature of publicinterest policy certainly depends on the ideas (or mission) of the relevant government officials (Kalt \& Zupan, 1984). Nevertheless, this sub-section adopts the mainstream national-welfare approach for evaluating the public interest merits of a merger; thus, leaving the impact of alternative public-interest definitions for the previous sub-section on institutional mission.

\footnotetext{
${ }^{5}$ As an aside, antitrust holdup might also be likely to occur in antitrust institutions moving from incapable to capable status. These agencies will need to establish credibility; hence, they may take some precedent setting 'strong' antitrust decisions. Recent 'hardline' decisions by the new Dutch antitrust agency may signal interest in being regarded as a very capable authority (van Damme, 2002).
} 
As already noted, antitrust policy is generally held to be the most public-interest driven of public policies; thus, implying that cross-national antitrust agencies are relatively strong and autonomous institutions (the implicit assumption in the one-way analysis). A number of scholars, nevertheless, argue that political pressures play a strong role in determining antitrust policy decisions (e.g., Faith, Leavens \& Tollison, 1982; Coate, Higgins \& McChesney, 1990). Further, a quick survey of cross-national antitrust agencies suggests that variation exists in institutional autonomy. For instance, Dutch antitrust officials have openly stated that industrial lobbies and other government institutions impact policy decisions (Cornielje, 2002). While US antitrust agencies are held to be highly autonomous, Coate, Higgins and McChesney (1990) imply that the Federal Trade Commission (FTC) is actually more susceptible to political pressure than the DOJ. Accordingly, three elements of antitrust institutional autonomyjurisdictional, decision, and budgetary-are identified here in order to better specify how institutional autonomy impacts the business-government interface with regard to antitrust policy.

Jurisdictional autonomy refers to whether an antitrust agency has sole jurisdiction over an antitrust decision or whether it must cede or share jurisdiction with another government body. Aplin and Hegarty’s (1980) terminology on ‘issue’ and ‘industry’ oriented governmental authorities helps clarify one main dynamic here. It is not uncommon for 'industry' oriented agencies to have primary or shared authority over mergers within that industry. For instance, Deutsche Telekom's acquisition of Voice Stream Wireless required approval not by US antitrust officials but by the Federal Communications Commission (Boston and Dreazen, 2001). Political economists posit that 'industry' oriented authorities — which deal with the same firms in a number of issue areas - might be more susceptible to capture or influence than ‘issue’ oriented agencies (Stigler, 1971). An example from the US airline industry illustrates: the Department of Transportation (DOT) had primary antitrust authority from 1985 through 
1988, while DOJ gained primary authority in 1989; all twenty-two airline mergers proposed under DOT jurisdiction were approved, while a number of airline mergers were restricted under DOJ jurisdiction (U.S. Congress, 1992). Canada's experience with the AirCanada/Canadian-Airlines merger exhibits an even more egregious loss of jurisdiction. In this case, the Canadian parliament temporarily rescinded the antitrust agency's authority in order to guarantee merger approval (Brokx, 2001). Antitrust authorities with jurisdictional autonomy may then better resist the political pressure of merging firms and the policy desires of other government institutions.

Decision autonomy refers to whether an antitrust agency has the final authority to make actual antitrust decisions. It is not uncommon to find antitrust agencies making recommendations for specific antitrust rulings; yet, these decisions must be approved by cabinet-level officials (OECD, 1998). The concern being that cabinet-level officials are more sensitive to political concerns than public-interest concerns. Boner and Krueger (1991) argue that giving judicial decisions — as opposed to administrative decisions - a central role in defining and enforcing antitrust law helps guarantee systematic focus on competition goals. Key is that administrative review of antitrust decisions opens the procedure up to political influences, while judicial reviews are less subject to such influences. Antitrust authorities with decision autonomy may then better resist the various political forces aiming to influence antitrust rulings.

Budgetary autonomy refers to the financial autonomy of an antitrust agency. As noted, budgets make up a critical element of institutional capability; yet, budgets also convey important information on institutional autonomy. Governments can be quite sensitive to budgetary fluctuations; hence, the more dependent an antitrust agency is on a specific administration's or legislature's favor for necessary funding, the greater the incentive to take political calculations into account when making policy decisions (Faith, Leavens \& Tollison, 1982; Coate, Higgins \& McChesney, 1990). For instance, the budget cuts for antitrust 
enforcement under the Reagan administration (Kwoka, 1999) certainly signaled a desired tenor for antitrust enforcement. Consequently, antitrust authorities with budgetary autonomy may better resist the political pressure of merging firms and the policy interests of other government institutions.

Accordingly, an antitrust agency's institutional autonomy impacts the reliability of the competitiveness insight from the one-way analysis. More autonomous antitrust institutions can focus on public interest criteria, while less autonomous institutions instead focus on the relevant constellation of political interests. As an example, Japan's antitrust authority has consistently found MITI, other government institutions, and the business community infringing upon its institutional space (Sanekata \& Wilks, 1996; Tilton, 1996). Since institutional autonomy is a necessary condition for public-interest antitrust policy, it is also necessary for the one-way propositions - the propositions will lack consistency when antitrust institutions are less autonomous. The following proposition captures the impact of institutional autonomy on the proffered one-way propositions:

Proposition 4: The more autonomous-in terms of jurisdiction, decision, and budget-the antitrust agency, the more an industry's global competitiveness will be able to predict the likely source-home or foreign—of antitrust holdup.

Figure 1 illustrates where the effect of proposition 4 (institutional autonomy mediating the prediction power of the one-way propositions) falls within the greater conceptual framework.

\section{IMPLICATIONS FOR EFFECTIVE POLITICAL STRATEGIES}

This section departs from the positive perspective taken by the previous sections and takes a normative perspective in order to yield more precise recommendations on how merging firms might successfully navigate the political-economic landscape for cross-national antitrust holdup. The aim is to yield relevant implications for effective political strategies-defined as the overall theme, and incumbent tactics, that businesses take to shape their non-market 
environment in order to "encourage policymakers to be more responsive to the interests of business" (Keim, 1981: 48). Recall, however, that antitrust policy is often considered to be public interest driven as opposed to private interest driven; thus, leaving merging firms with relatively little agency upon which to act in the political arena. Some scholars, nevertheless, have considered antitrust outcomes to be partially subject to political pressure (e.g., Pittman, 1977; Faith, Leavens \& Tollison, 1982; Coate, Higgins \& McChesney, 1990; Neven, Papandropoulos \& Seabright, 1998; Clougherty, 2003). For example, Neven, Papandropoulos and Seabright (1998) show that merging firms facing antitrust scrutiny engage in lobbying activities. Accordingly, we move forward realizing the potential for merging firms to have a marginal impact (partial agency) vis-à-vis antitrust outcomes—a marginal impact that needs to be factored. Further, the limited ability of merging-firms to influence antitrust outcomes mandates optimal use of political resources if they are to yield effective outcomes. In short, this section uses the insights from positive propositions in the previous sections in order to formulate effective corporate political strategies.

First, recall from the one-way analysis that propositions $1 \mathrm{a}$ and $1 \mathrm{~b}$ collectively suggest—and the empirical evidence supports — that merger-reviews most likely emanate from net-importer nations. Net-exporter nations experience large post-merger producer gains due to substantial profit gains in foreign markets; thus, net-exporter nations likely find domestic mergers (whether home or foreign) to enhance national welfare. Yet, net-importer nations experience small post-merger producer gains due to insubstantial profit gains in foreign markets; thus, net-importer nations likely find domestic mergers (whether home or foreign) to reduce national welfare. Accordingly, antitrust holdup likely originates from nations with netimporter profiles in a particular industry. Merging firms would thus be best off directing political pressure at the net-importer nation's antitrust authority. The following proposition draws a simple normative implication from this discussion: 
Proposition 5: Merging firms best direct their limited political resources and their political strategy tactics toward the antitrust agencies of net-importer nations - may they be home or foreign nations - as these institutions are more likely to engage in antitrust holdup activities.

Proposition 5 does not test readers’ cognitive abilities, but does underscore that firms retain some agency concerning the business-government interface for antitrust. See figure 1 for a representation of where the proposition falls within the greater conceptual framework.

Next, recall that institutional mission impacts the effectiveness of the global competitiveness insight: i.e., the one-way propositions hold best when the mission of antitrust agencies includes the promotion of competition issues and the consideration of internationalcompetitive-effects (Proposition 2). From a normative perspective, the various elements of institutional mission provide vulnerability points for merging firms engaged in lobbying. Hillman and Keim (1995) contend that different political systems yield different vulnerability points for successful political pressure. In the same vein-though narrowing the level of analysis to the institutional level-I contend that antitrust institutional objectives provide vulnerability points for political pressure. It is important to first understand that public policies supported by both private and public interest political forces encounter more success and are more-fully implemented than policies supported by only one political force (Becker, 1983; Mansfield \& Busch, 1994; Clougherty, 2003). Baysinger (1984: 257) states "in pursuing their selfish political objectives, businesses may promote beneficial social policy". Schuler (1996) manifests the importance of integrating political pressure with public interest criterion when he shows how US steel makers used government policy instruments to secure their position in a declining industry.

Accordingly, it behooves firms facing antitrust holdup to target their political pressure in tandem with non-competition concerns: i.e., industrial, employment and regional policies. The source of antitrust holdup might be more difficult to predict when authorities consider 
non-competition issues as public interest criterion; yet by targeting the non-competition mission of an antitrust agency, merging firms increase the probability of obtaining antitrust approval. Further, international-competitive-effects are an additional policy feature that merging firms can target. Domestic mergers with positive international-competitive-effects might be accepted on their own merits a la the one-way propositions; yet, merging firm pressure that reminds antitrust authorities of national welfare benefits will ensure public interest support (Clougherty, 2003). The impact of institutional mission on the effectiveness of merging firms' political pressure is captured by the following proposition:

Proposition 6: Merging firms' political pressure will be more effective when political tactics target an element (e.g., international-competitive-effects, regional, employment or industrial policy) of an antitrust agency's mission.

Recall also that institutional capability impacts the effectiveness of the global competitiveness insight: i.e., the one-way propositions hold best when antitrust agencies are capable in terms of political legitimacy, budgetary support and personnel expertise (Proposition 3). From a normative perspective, institutional capability provides some evidence on the optimal political tactics which merging firms might employ. ${ }^{6}$ Management researchers (e.g., Aplin \& Hegarty, 1980; Baysinger, 1984; Getz, 1993) have proposed many typologies for the various political tactics adopted by businesses. The underlying point here is that different political tactics more readily exploit different institutional capability vulnerabilities. First, antitrust agencies lacking in legitimacy might be vulnerable to firms engaging in political tactics that create broad-based support for a policy position. Constituency and coalition building, grass-roots lobbying, and public appeals-are all tactics which might create the legitimacy which an antitrust agency lacks. Second, antitrust agencies lacking in budgetary support might be vulnerable to firms engaging in political tactics that impact the budgetary

\footnotetext{
${ }^{6}$ As an aside, two points should be understood here: 1 ) incapable antitrust institutions will still periodically engage in antitrust holdup; 2) actual antitrust agencies exhibit variation in the different elements of institutional capability.
} 
situation of an antitrust agency. For instance, legal tactics may be quite successful when antitrust authorities can't fund an adequate defense. Further-and more unseemly—scholars have noted the susceptibility of underpaid bureaucrats to financial lures (Krueger, 1974). Hence, 'direct' political contributions might be successful political tactics; though, certainly dangerous and of questionable ethics (Yoffie, 1987; Post, Lawrence, \& Weber, 1999). Third, antitrust agencies lacking in personnel expertise might be vulnerable to firms engaging in tactics that provide necessary expertise. Political tactics that focus on spreading informationtestifying, and reporting research and survey results (e.g., Getz, 1993)—might fill the information void within the antitrust agency. Political tactics that involve personnel service by firm representatives in government (Hillman, Zardkoohi \& Bierman, 1999) might also create the expertise required by antitrust authorities. In short, under-talented institutions are susceptible to the strategic use of information (Milgrom, 1988; Milgrom \& Roberts, 1988). The impact of institutional capability on the effectiveness of merging firms' political pressure is captured by the following proposition:

Proposition 7: Merging firms' political pressure will be more effective when political tactics address lacking elements (legitimacy, budget, personnel) of an antitrust agency's institutional capability.

Recall that institutional autonomy impacts the effectiveness of the global competitiveness insight: i.e., the one-way propositions hold best when antitrust agencies are relatively autonomous in terms of jurisdiction, decision and budget (Proposition 4). From a normative perspective, the autonomy of an antitrust authority impacts its vulnerability to political pressure: less autonomous antitrust authorities are simply more vulnerable to political pressure. Key is that when antitrust authorities tenuously hold their institutional ground, they are ripe for influence by merging firms (Clougherty, 2003). Merging firms may directly pressure weak antitrust agencies or do so via other government institutions (Coate, Higgins, \& McChesney, 1990). Less autonomous antitrust agencies call less for subtle political tactics 
(e.g., information, coalition \& constituency building, and grass-roots lobbying), as many forms of political pressure (direct and indirect) will be relatively effective. The impact of institutional autonomy on the effectiveness of merging firms' political pressures is captured by the following proposition:

Proposition 8: Merging firms' political pressure will be more effective when an antitrust agency has less autonomy in terms of jurisdiction, decision and budget. In sum, propositions' 6,7 and 8 suggest that the mission, capability and autonomy of the relevant antitrust agency mediate the effectiveness of merging firms’ political pressure.

\section{DISCUSSION \& CONCLUSION}

Uncertainty over the source of antitrust holdup (home or foreign based) is essentially a new issue facing business. Previously, domestic mergers seldom involved significant international-competitive-effects; further, the few domestic mergers involving significant international effects were likely to take place in an environment of lenient antitrust policy. Yet as already noted, many nations are strengthening their antitrust regulations, and globalization is fast fictionalizing the notion that a domestic merger can take place without international implications. These trends suggest that merging firms will increasingly face a dilemma over where holdup is likely to emanate from, and where political resources are optimally placed.

The principal aim of this work was to propose a conceptual framework that predicts the source of antitrust holdup for domestic mergers; thus, yielding insights as to where political pressure might optimally be applied (see figure 1 where the framework and constituent propositions are illustrated). The framework and the analysis are nested within the corporate political strategy (CPS) literature; however, this work necessarily takes a leap forward, as little literature exists on the study of the business-government interface regarding antitrust policy. It is certainly odd to be studying the business-government interface for domestic mergers involving potential scrutiny from both home and foreign antitrust authorities, when the 
business-government interface regarding purely domestic mergers (i.e., no international effects) has not been adequately studied. Nevertheless, neither this paper nor reality can wait for the relatively slow pace of management research concerning business-government interaction (Epstein, 1980; Shaffer, 1995). Globalization's increased reach-with its raised antitrust standards, and greater link between domestic and international competitive outcomes-into formerly domestic political-economic concerns particularly accelerates the demand for research of this nature.

\section{Summary}

In delivering on the principal aim (creating a conceptual framework to predict antitrust holdup source), five specific analyses were taken. First, the concept of antitrust holdup is defined within the managerial context. Second, the primary driver behind antitrust holdup source was derived under idealized institutional conditions (the one-way analysis). Third, the contention that trade-balance determines the level of antitrust-scrutiny was empirically supported. Fourth, the idealized institutional conditions were relaxed to allow cross-national variation in the institutional context for antitrust. Fifth, a normative perspective was adopted to yield political strategy implications for how merging firms might successfully navigate the political-economic landscape for cross-national antitrust holdup.

First, I clarify the concept of antitrust holdup as it plays a fundamental role in the analysis. Antitrust holdup is considered to be any action taken by antitrust authorities that negatively effects firms by delaying the onset of the intended merger, by restricting the nature of the intended merger, or by preventing the intended merger. Further, I outline some of the benefits for firms being able to predict the source (home-nation or foreign-nation) of antitrust holdup. Potential benefits include assisting firms in making optimal target choices, avoiding lengthy merger reviews when time is of the essence, and directing political resources to the most important authorities. 
Second, I derive a primary determining factor to help predict the source (home or foreign) of antitrust holdup. I argue that an industry' global competitiveness—reflected by trade-balance-plays a determining role in explaining whether home or foreign antitrust authorities engage in holdup. Domestic mergers occurring in net-exporter nations more likely find antitrust holdup coming from foreign authorities than from home authorities. Conversely, domestic mergers occurring in net-importer nations more likely find antitrust holdup coming from home authorities than from foreign authorities.

Third, I empirically test the essence of the above argument: which can be reduced to positive trade balances enhancing the national welfare merits of lenient merger policy. In other words, net-exporter profiles encourage antitrust authorities to be more lax with regard to both home and foreign domestic mergers. The empirical tests-based on panel data covering 27 antitrust jurisdictions over the 1992-2000 period-support net-exporter nations being more lenient with regard to merger reviews; thus, supporting the existence of the primary dynamic behind the proposed conceptual framework.

Fourth, I relaxed the assumption of idealized institutional conditions and considered the implications of cross-national institutional variation for antitrust policy. I found the one-way propositions—regarding the impact of an industry's global competitiveness on antitrust holdup source-to be mediated by institutional qualities. More specifically, the one-way propositions hold best when the antitrust agency is autonomous and capable, and when its mission includes the promotion of competition issues and the consideration of international competitive effects.

Fifth, I re-analyzed the positive political-economy constructs embedded in the above analyses with a normative perspective to yield recommendations for effective use of political strategies. With regard to where merging firms might optimally locate and apply limited political resources, I find merging firms' political pressure to be best directed at the antitrust authorities (whether home or foreign) of net-importing nations. Further, merging firms' political pressure will be more effective when targeting an element of an antitrust agency's 
mission: i.e., political pressure targeted in tandem with industrial, employment and regional policy concerns (as well international-competitive-effects mandates) will robustly impact merger policy outcomes. Additionally, political tactics that take into account lacking elements (vis-à-vis legitimacy, budget and personnel) of an antitrust agency's institutional capability will be relatively effective. Lastly, merging firms' political pressure will be more effective when an antitrust agency has less autonomy with respect to jurisdictional, decision and budgetary issues.

\section{Future Research}

The point has already been made that this conceptual framework for the businessgovernment interface with regard to antitrust policy makes a leap forward in addressing a current and growing concern for firms engaging in domestic mergers. Unfortunately, the analysis does not rest upon a large body of literature that analyzes the business-government interface concerning antitrust policy for domestic mergers in a non-global world: i.e., a world where the majority of the political economic effects from a domestic merger are restricted to the nation state. An obvious future research direction would be to fill in the ground this analysis skips by building the systematic conditions concerning the business-government interaction for strictly domestic mergers: i.e., domestic both in terms corporate headquarters and competitive effects.

The main contribution of mapping the cross-national context for managerial decisions regarding the business-government interaction is certainly valuable in itself. Nevertheless, by focusing on the external environment (with the ensuing opportunities and threats) for crossnational antitrust holdup, I under-represent two additional areas that are fundamental to strategy research: 1) internal environment; 2) strategy formulation.

First, an obvious area for future research could be extending the analysis to the internal situation for firms dealing with the business-government interface for antitrust policy. The 
resource-based perspective (Penrose, 1959; Wernerfelt, 1984; Barney, 1991) might then complement the current analysis, which is now framed by the CPS literature and draws heavily for theoretical support from the industrial organization and political economy literatures. As such the conceptual framework mimics the course of the strategy literature by first giving emphasis to external conditions: both market and political-institutional in this case. The principal finding by Hillman, Zardkoohi \& Bierman (1999) — that firms with representatives serving in political capacities have higher firm values - indicates the potential benefits of firmspecific analysis. Barney (2001) begins an effort to marry research in antitrust economics with the management literature on what he calls 'capability theory'. Consequently, by neglecting what might be the unique and inimitable traits of various merging firms, this analysis risks being as incomplete as the strategy literature's focus on the external environment (Conner, 1991). Scholars might then develop a model encompassing the external perspective contained here and an internal (or 'capability') perspective for the business-government interface concerning antitrust policy.

Second, the conceptual framework could gain from focusing more on strategy formulation elements. The necessary first step of illuminating the various opportunities and threats in the cross-national institutional environment for merger-reviews has certainly been taken. Further, I take steps to yield implications for effective political strategies by considering which political tactics might best fit within the cross-national institutional context for antitrust. Yet, Yoffie and Kwak (2001) undertake an internal analysis that considers the genesis of how Intel's compliance strategy helped avoid serious antitrust holdup despite its strategic partnership and similar competitive position to Microsoft. Consequently, efforts that consider how firms facing significant antitrust scrutiny avoid holdup and implement their political strategies might be very helpful in further building theory.

The most obvious area for future research lies in additional empirical testing of the conceptual framework and constituent propositions. The current state of data does not allow a 
full testing of the proposed conceptual framework: first, because detailed data on the characteristics of cross-national antitrust institutions is lacking; second, because more precise sector-level or firm-level data is lacking for testing the proposed primary force behind the conceptual framework. Nevertheless, the reported exploratory empirical tests do provide support for the primal role of trade-balance in explaining antitrust holdup source. While empiricists should be aware that the state of cross-national data on antitrust scrutiny is quite primitive (Horn \& Levinsohn, 2001), the conceptual framework and the contingent propositions readily lend themselves to empirical testing. Note that ready empirical testing is one potential reason for the imbalance in empirical work between the external and internal perspectives on firm profitability (Barney, 2001). Consequently, management research on business-government interaction may unavoidably follow the path of the strategy literature.

In concluding, it is worth echoing the calls of Epstein (1980), Mitnick (1993) and Vogel (1996) for greater systematic efforts in analyzing the business-government interface. Management scholars are well poised and well armed to investigate the two-way relationship between firm strategies and public policy. The dearth of management scholarship concerning the business-government interface regarding antitrust policy is particularly 'shaming' in light of the breadth of management scholarship in the other dimensions of mergers \& acquisitions. Management scholars should then continue the theory building process-with the accordant proposition formulation and empirical testing-concerning the business-government interface. The time for abstract agenda-setting scholarship has simply passed. This paper does its part: first, by moving theoretical work toward the middle range-the provision of logical explanations for certain behaviors and outcomes_of theory (Mitnick, 2001); second, by engaging in empirical testing —albeit partial—of proposed theoretical constructs. 


\section{REFERENCES}

Aplin, J.C. \& Hegarty, W.H. 1980. Political Influence: Strategies Employed by Organizations to Impact legislation in Business and Economic Matters. Academy of Management Journal, 23(3): 438-450.

Auletta, K. 2001. World War 3.0: Microsoft and its Enemies. Random House.

Bare Act. 1999. The Monopolies and Restrictive Trade Practices Act, 1969. Delhi, India: Universal Law Publishing.

Barney, J.B. 1991. Firm Resources and Sustained Competitive Advantage. Journal of Management, 17: 99-120.

Barney, J.B. 2001. Competence Explanations of Economic Profits in Strategic Management: Some Policy Implications. Paper Presented at the Academy of Management Meetings, Washington DC.

Barros, P.P. \& Cabral L. 1994. Merger Policy in Open Economies. European Economic Review, 38: 1041-1055.

Baysinger, B.D. 1984. Domain maintenance as an objective of business political activity: An expanded typology. Academy of Management Review, 9: 248-258.

Becker, G.S. 1983. A theory of competition among pressure groups for political influence. Quarterly Journal of Economics, 98: 371-400.

Bentley, A.F. 1908. The Process of Government. Chicago: University of Chicago Press.

Bittlingmayer, B. 1985. Did Antitrust Policy Cause the Great Merger Wave?. Journal of Law \& Economics, 28: 77-118.

Boddewyn, J.J. \& Brewer, T.L. 1994. International-Business Political Behavior: New Theoretical Directions. Academy of Management Review, 19(1): 119-143.

Boner, R. A. \& Krueger, R. 1991. The Basics of Antitrust Policy: A Review of Ten Nations and the European Communities. World Bank Technical Papers, No. 160, Washington DC: The World Bank.

Boston, W. \& Dreazen, Y.J. 2001. U.S. Appears Poised to Approve Deutsche Telekom Acquisition. Wall Street Journal Europe, Thursday, April 5, 2001: 1.

Bouwman, T. 1995. The 1995 Mediawars in Holland. Before the International Federation of the Periodical Press (FIPP) Congress. On September 27, 1995.

Brokx, L. 2001. A Patchwork of Leniency Programmes. European Competition Law Review. 22(2): 35-46.

Campbell, A.N., \& Trebilcock, M.J. 1997. Interjurisdictional Conflict in Merger Review. In L. Waverman, W.S. Comanor \& A. Gato (Eds.), Competition Policy in the Global Economy: London \& New York: Routledge. 
Clougherty, J.A. 2001 Globalization and the Autonomy of Domestic Competition-Policy: An Empirical Test on the World Airline Industry. Journal of International Business Studies, 32(3): 459-478.

Clougherty, J.A. 2003. Nonmarket Strategy for Merger Reviews: The Roles of Institutional Independence and International Competitive Effects. Business \& Society, 42(1): 115-143.

Cornielje, O. 2002. Tight oligopolies. Before the 'Competition Act Under Review' Workshop. On April 9, 2002.

Coate, M.B., Higgins, R.S. \& McChesney F.S., 1990. Bureaucracy and Politics in FTC Merger Challenges, Journal of Law and Economics, 33: 463-482.

Competition Bureau. 1991. Merger Enforcement Guidelines. Canada: Government of Canada.

Conner, K.R. 1991. A historical comparison of resource-based theory and five schools of thought within industrial organization economics: Do we have a new theory of the firm?. Journal of Management, 17: 121-154.

Delios, A. \& Henisz, W.J. 2003. Political hazards, experience, and sequential entry strategies: the international expansion of Japanese firms, 1980-1998. Strategic Management Journal, 24(11): 1153-1164.

Doern, G.B. 1996. Comparative Competition Policy: Boundaries and Levels of Political Analaysis. In G.B. Doern \& S. Wilks (Eds.), Comparative Competition Policy: National Institutions in a Global Market: 7-39. Oxford: Clarendon Press.

Downs, A. 1957. An Economic Theory of Democracy. New York: Harper \& Row.

Drucker, P.F. 1974. Management-Tasks, Responsibilities, Practices. New York: Harper \& Row.

Dunning, J.H. 1997. Introduction. In J.H. Dunning (Ed), Governments, Globalization, and International Business. Oxford: Oxford University Press, 1997.

Dutz, M.A. \& Vagliasindi, M. 2000. Competition policy implementation in transition economies: An empirical assessment. European Economic Review. 44: 762-772.

Eckbo, B.E. \& Wier, P. 1985. Antimerger Policy under the Hart-Scott-Rodino Act: A Reexaminaton of the Market-Power Hypothesis, Journal of Law \& Economics, 28: 119-149.

Epstein, E. 1969. The Corporation in American Politics. Englewood Cliffs NJ: Prentice Hall.

Epstein, E. 1980. Business political activity: Research approaches and analytical issues. In L. Preston (Ed.), Research in corporate social performance and policy, Vol. 2. Greewich, CT: JAI Press.

European Commission, 2000. External and intra-European Union trade-Statistical yearbook. Luxembourg: Office for the Official Publication of the European Communities.

Evans, P. 1995. Embedded Autonomy: States and Industrial Transformation, Princeton: Princeton University Press. 
Farrell, J. \& Shapiro, C. 1990. Horizontal Mergers: An Equilibrium Analysis. American Economic Review, 80(1): 107-126.

Faith, R.L., Leavens, D.R. \& Tollison, R.D. 1982. Antitrust Pork Barrel. Journal of Law and Economics, 25: 329-42.

Fisher, F.M. 1987. Horizontal Mergers: Triage and Treatment. Journal of Economic Perspectives, 1: 23-40.

Getz, K.A. 1993. Selecting Corporate Political Tactics. In B.M. Mitnick (ed.), Corporate Political Agency: The Construction of Competition in Public Affairs: 242-273. Newbury Park CA: Sage publications.

Goldstein, J. 1989. The Impact of Ideas on Trade Policy: The Origins of U.S. Agricultural and Manufacturing Policies. World Politics, 43(1): 31-71.

Goldstein, J. 1993. Ideas, Interests and American Trade Policy. Ithaca: Cornell University Press.

Goldstein, J. \& Keohane, R.O. 1993. Ideas and Foreign Policy: An Analytical Framework. In J. Goldstein \& R.O. Keohane (Eds.) Ideas and Foreign Policy: Beliefs, Institutions, and Political Change: 3-30. Ithaca: Cornell University Press.

Goldstein, J. \& Lenway, S.A. 1989. Interests or Institutions: An Inquiry into CongressionalITC Relations. International Studies Quarterly, 33(1): 303-327.

Graham, E.M. \& Warner, M.A.A. 1994. Multinationals and Competition Policy in North America. In L. Eden (ed), Multinationals in North America. Calgary: University of Calgary Press.

Graham, E.M. \& Richardson, J.D. 1997. Conclusions and Recommendations. In E.M. Graham \& J.D. Richardson (Eds.), Global Competition Policy. Washington DC: Institute for International Economics.

Greene, W.H. 1990. Econometric Analysis. Macmillan, New York.

Head, K. \& Ries, J. 1997. International mergers and welfare under decentralized competition policy. Canadian Journal of Economics, 30(4b): 1104-1123.

Henisz, W.J. \& Zelner B.A. 2001. The Institutional Environment for Telecommunications Investment. Journal of Economics and Management Strategy, 10(1): 123-148.

Hill, C.W.L. \& Jones, G.R. 2004. Strategic Management: An Integrated Approach. Boston: Houghton Mifflin Company.

Hillman, A.J., \& Keim. G., 1995. International Variation in the Business-Government Interface: Institutional and Organizational Considerations. Academy of Management Review, 20(1): 193214.

Hillman, A.J., \& Hitt. M., 1999. Corporate political strategy formulation: a model of approach, participation, and strategy decisions. Academy of Management Review, 24(4): 825-842. 
Hillman, A.J., Zardkoohi, A. \& Bierman, L. 1999. Corporate Political Strategies and Firm Performance: Indications of Firm-Specific Benefits from Personal Service in the US Government. Strategic Management Journal, 20: 67-81.

Horn, H. \& Levinsohn, J. 2001. Merger Policies and Trade Liberalization. The Economic Journal, 111: 244-276.

Kalt, J.P. and M.A. Zupan, 1984. Capture and Ideology in the Economic Theory of Politics. American Economic Review, 74(3): 279-300.

Keim, G.D., 1981. Foundations of a Political Strategy for Businesses. California Management Review, 23(3): 41-48.

Keim, G.D., \& Baysinger, B.D. 1988. The Efficacy of Business Political Activity: Competitive Considerations in a Principal-Agent Context. Journal of Management, 14(2): 163-180.

Keim, G.D., \& Zeithaml, C.P. 1986. Corporate Political Strategies and legislative decision making: A review and contingency approach. Academy of Management Review, 11: 828-843.

Khanna, T. \& Rivkin, J.W. 2001. Estimating the Performance Effects of Business Groups in Emerging Markets. Strategic Management Journal, 22(1): 45-74.

Kovacic, W.E. 1992. The Influence of Economics on Antitrust Law. Economic Inquiry, 30(2): 294-306.

Kovacic, W.E. \& Shapiro C. 2000. Antitrust Policy: A Century of Economic and Legal Thinking. Journal of Economic Perspectives, 14(1): 43-60.

Krueger, A.O. 1974. The political economy of the rent-seeking society. American Economic Review, 64: 291-303.

Kwoka, J.E. 1999. Commitment to Competition: An Assesment of Antitrust Agency Budgets since 1970. Review of Industrial Organization. 14: 295-302.

Lenway, S.A., \& Murtha, T.P. 1994. The State as Strategist in International Business Research. Journal of International Business Studies, 25: 513-535.

Lenway, S.A., \& Rehbein K., 1991. Leaders, Followers and Free Riders: an Empirical Test of Variation in Corporate Political Involvement. Academy of Management Journal, 34(4): 893905.

Levinsohn, J. 1997. Competition Policy and International Trade. In J.N. Bhagwati \& R.E. Hudec (Eds.) Fair Trade and Harmonization: Prerequisites for Free Trade?. Cambridge MA: The MIT Press.

Long, W.F., Schramm, R., \& Tollison, R.D. 1973. The Economic Determinants of Antitrust Activity. Journal of Law \& Economics, 16: 351-364.

Mansfield, E. and M. Busch, 1994. Political Economy of Non-Tariff Barriers. Discussion Paper No. 39, Center for International Studies, University of Southern California. 
McChesney, F.S. and Shughart W.F. II, 1995. Introduction and Overview. In F.S. McChesney and W.F. Shughart II (Eds.), The Causes and Consequences of Anti-trust - The Public Choice Perspective: 1-5, Chicago: University of Chicago Press.

Melamed, A.D. 2000. Promoting Sound Antitrust Enforcement in the Global Economy. Address by the Acting Assistant Attorney General, Antitrust Division, U.S. Department of Justice. Before the Fordham Corporate Law Insititute: $27^{\text {th }}$ Annual Conference on International Antitrut Law and Policy. On October 19, 2000 in New York, NY.

Meuller, D.C. 1997. Merger Policy in the United States: A Reconsideration. Review of Industrial Organization, 12: 655-685.

Milgrom, P. 1988. Employment contracts, influence activities and organization design. Journal of Political Economy, 96:42-60.

Milgrom, P. \& Roberts J. 1988. An Economic approach to influence activities in organizations. American Journal of Sociology, 94:S154-S179.

Milner, H.V. \& Keohane R.O., 1996. Internationalization and domestic politics: An introduction. In R.O. Keohane \& H.V. Milner (eds.), Internationalization and domestic politics: 3-24, Cambridge: Cambridge University Press.

Mitnick, Barry M. (ed.), 1993. Corporate Political Agency: The Construction of Competition in Public Affairs, Newbury Park CA: Sage Publications.

Mitnick, B.M. 2001. The Uses of Political Markets. Paper Presented at the Academy of Management Meetings, Washington DC.

Murtha, T. \& Lenway, S.A. 1994. Country Capabilities and the Strategic State: how national political institutions affect multinational corporations' strategies. Strategic Management Journal. 15: 113-129.

Neumann, M. 1990. Industrial Policy and Competition Policy. European Economic Review. 34: 562-567.

Neven, D., Papandropoulos, P. \& Seabright, P. 1998. Trawling for Minnows: European Competition Policy \& Agreements Between Firms, London: Centre for Economic Policy Research.

North, D.C. 1981. Structure and Change in Economic History, New York \& London: W.W. Norton \& Co.

North, D.C. 1990. Institutions, Institutional Change and Economic Performance, Cambridge: Cambridge University Press.

Nilssen, T. 1997. On the consistency of merger policy. Journal of Industrial Economics, XLV(1): 89-100.

OECD, 1992-2000. Competition Policy in OECD Countries. Paris: OECD. 
O’Shaughnessy, K.C., \& Flanagan, D.J. 1998. Determinants of Layoff Announcements Following M\&As: An Empirical investigation. Strategic Management Journal, 19(10): 9891000.

Ostry, S. 1997. Globalization, Domestic Policies and The Need for Harmonization. In L. Waverman, W.S. Comanor \& A. Gato (Eds.), Competition Policy in the Global Economy: Modalities for Cooperation. London \& New York: Routledge.

Penrose, E. 1959. The theory of the growth of the firm. New York: Wiley.

Pittman, R. 1977. Market Structure and Campaign Contributions. Public Choice, 31:37-58.

Post, J.E., Lawrence, A.T. \& Weber J., 1999. Business and Society: Corporate Strategy, Public Policy, Ethics. Boston: Irwin McGraw-Hill.

Priem, R.L. \& Butler, J.E. 2001. Is the resource-based “view” a useful perspective for strategic management research? Academy of Management Review, 26(1): 22-40.

Rubin, P.H. 1995. What Do Economists Think about Antitrust?: A Random Walk Down Pennsylvania Avenue. In F.S. McChesney and W.F. Shughart II (Eds.), The Causes and Consequences of Anti-trust - The Public Choice Perspective: 33-61, Chicago: University of Chicago Press.

Rumelt, R., Teece, D. \& Schendel, D. 1991. Strategic Management and Economics. Strategic Management Journal, 12: 5-29.

Sanekata, K. \& Wilks S. 1996. The Fair Trade Commission and the Enforcement of Competition Policy in Japan. In G.B. Doern \& S. Wilks (Eds.), Comparative Competition Policy: National Institutions in a Global Market: 102-138. Oxford: Clarendon Press.

Scherer, F.M. 1996. International Trade and Competition Policy. Discussion Paper No. 96-18, Zew Industrial Economics and International Management Series, Mannheim Germany.

Schuler, D.A., 1996. Corporate Political Strategy and Foreign Competition: The Case of the Steel industry. Academy of Management Journal, 39(3): 720-737.

Schumpeter, J., 1950. Capitalism, Socialism, and Democracy. New York: Harper \& Brothers.

Shaffer, B. 1995. Firm-level Responses to Government Regulation: Theoretical and Research Approaches. Journal of Management, 21(3): 495-514.

Sirower, M.L., 1997. The synergy trap: how companies lose the acquisition game. New York: The Free Press.

Sorgard, L. 1997. Domestic merger policy in an international oligopoly: The Nordic market for electricity. Energy Economics, 19: 239-53.

Stigler, G.J., 1971. The Theory of Economic Regulation. Bell Journal of Economic and Management Science, 2: 3-21.

The Economist. 1999. Industrial gases: Under pressure. June 24. 
The Economist. 2000. Europe's merger morass. September 23.

The Economist. 2001a. GE/Honeywell: Welch squelched. June 23: 73.

The Economist. 2001b. Antitrust: Merger muddle. June 23: 13-14.

The Economist. 2001c. Consolidate or liquidate. December 6.

Tilton, M. 1996. Restrained Trade: Cartels in Japan's Basic Materials Industries. Ithaca: Cornell University Press.

Trebilcock, M.J. 1996. Reconciling Competition Laws and Trade Policies: A New Challenge to International Co-operation. In G.B. Doern \& S. Wilks (Eds.), Comparative Competition Policy: National Institutions in a Global Market: 268-301. Oxford: Clarendon Press.

Truman, D. 1951. The Governmental Process. New York: Knopf.

U.S. Congress, Senate, AdHoc Subcommittee on Consumer \& Environmental Affairs, Fewer Airlines, Higher Fares, 102nd Congress, 2nd Session, 21 February 1992.

U.S. DOJ. 1998. Antitrust Division Manual. Washington DC: U.S. Department of JusticeAntitrust Division.

U.S. GAO. 1973. Clarifying Webb-Pomerene Act Needed to Help Increase U.S. Exports. Washington DC: U.S. General Accounting Office.

Vachris, M.A. 1996. Federal antitrust enforcement: A principal-agent perspective. Public Choice, 88: 223-238.

van Damme, E. 2002. The judgement of vertical relations in antitrust cases. Before the 'Competition Act Under Review’ Workshop. On April 9, 2002.

Vogel, D.J., 1996. The Study of Business and Politics. California Management Review, 38(3): 146-165.

Waldman, D.E. 1985. The Economics of Antitrust: Cases and Analysis. Boston: Little Brown and Co.

Wall, L.D. \& Eisenbeis, R.A. 2000. Financial Regulatory Structure and the Resolution of Conflicting Goals, Journal of Financial Services Research, 17(1): 223-245.

Wernerfelt, B. 1984. A resource-based view of the firm. Strategic Management Journal, 5: 171-180.

White, L.J. 1987. Antitrust and Merger Policy: A Review and Critique. Journal of Economic Perspectives, 1: 13-22.

Williamson, O.E., 1968. Economies as an Antitrust Defense: The Welfare Tradeoffs. American Economic Review, 58: 18-36. 
Yandle, B. 1995. The Positive Economics of Antitrust Enforcement. In F.S. McChesney and W.F. Shughart II (Eds.), The Causes and Consequences of Anti-trust - The Public Choice Perspective: 119-126, Chicago: University of Chicago Press.

Yano, M. 2001. Trade Imbalance and Domestic Market Competition Policy. International Economic Review, 42(3): 729-750.

Yoffie, D.B. 1987. Corporate Strategies for Political Action: A Rational Model. In Marcus, Kaufman \& Beam (Eds.), Business Strategy and Public Policy. New York: Qurom Books.

Yoffie, D.B. \& Kwak, M. 2001. Playing by the Rules: how intel avoids antitrust litigation. Harvard Business Review. 79(6): 119-122.

Zhang, A. \& Chen, H. 2002. Horizontal Mergers in a Liberalizing World Economy. Pacific Economic Review, 7(2): 1-18. 
FIGURE 1

A Framework for Evaluating the Source of Antitrust Holdup \& the Optimal Placement and Nature of Merging-Firm's Political Pressure

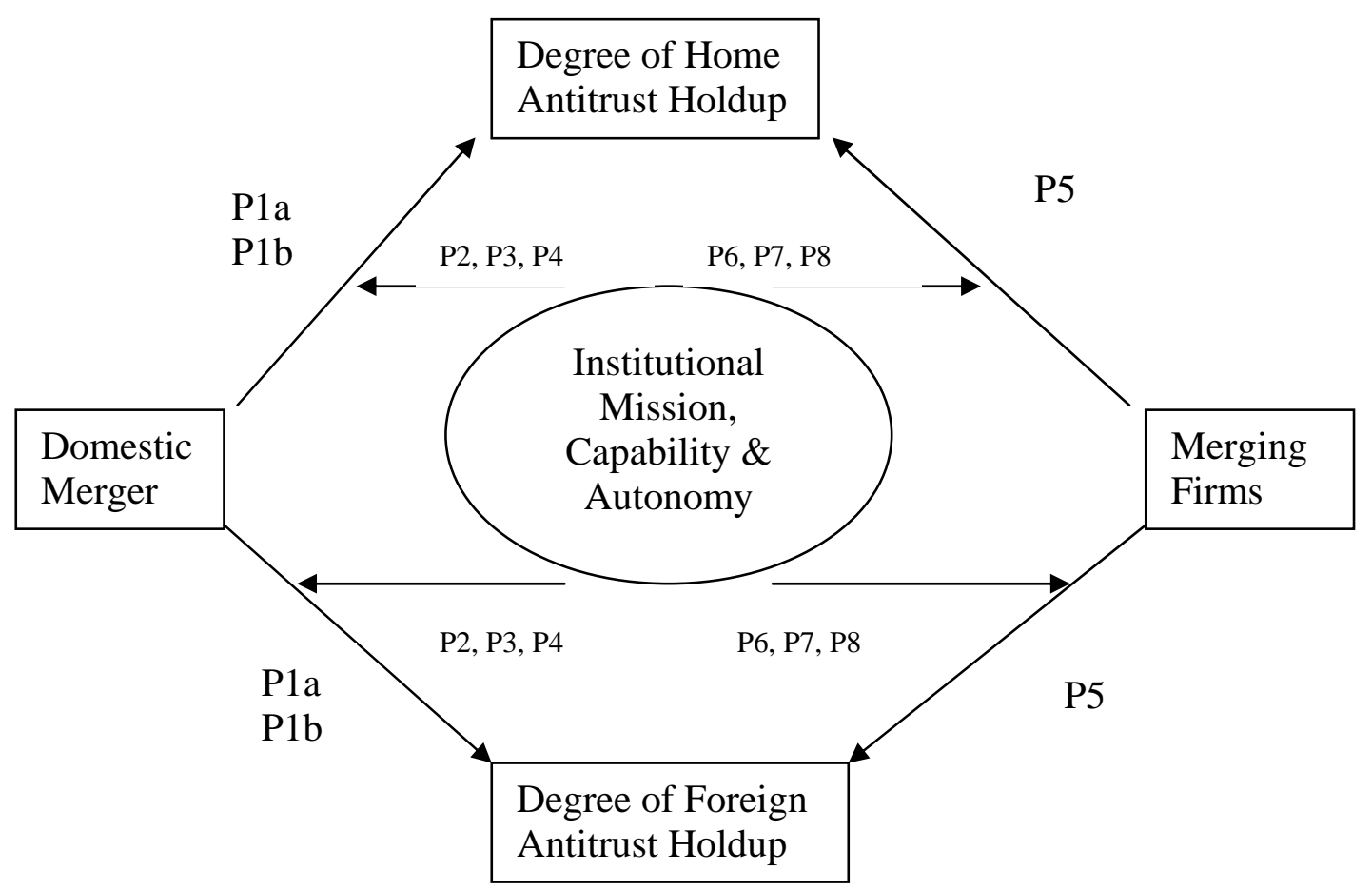


Figure 2: Antitrust Holdup Index

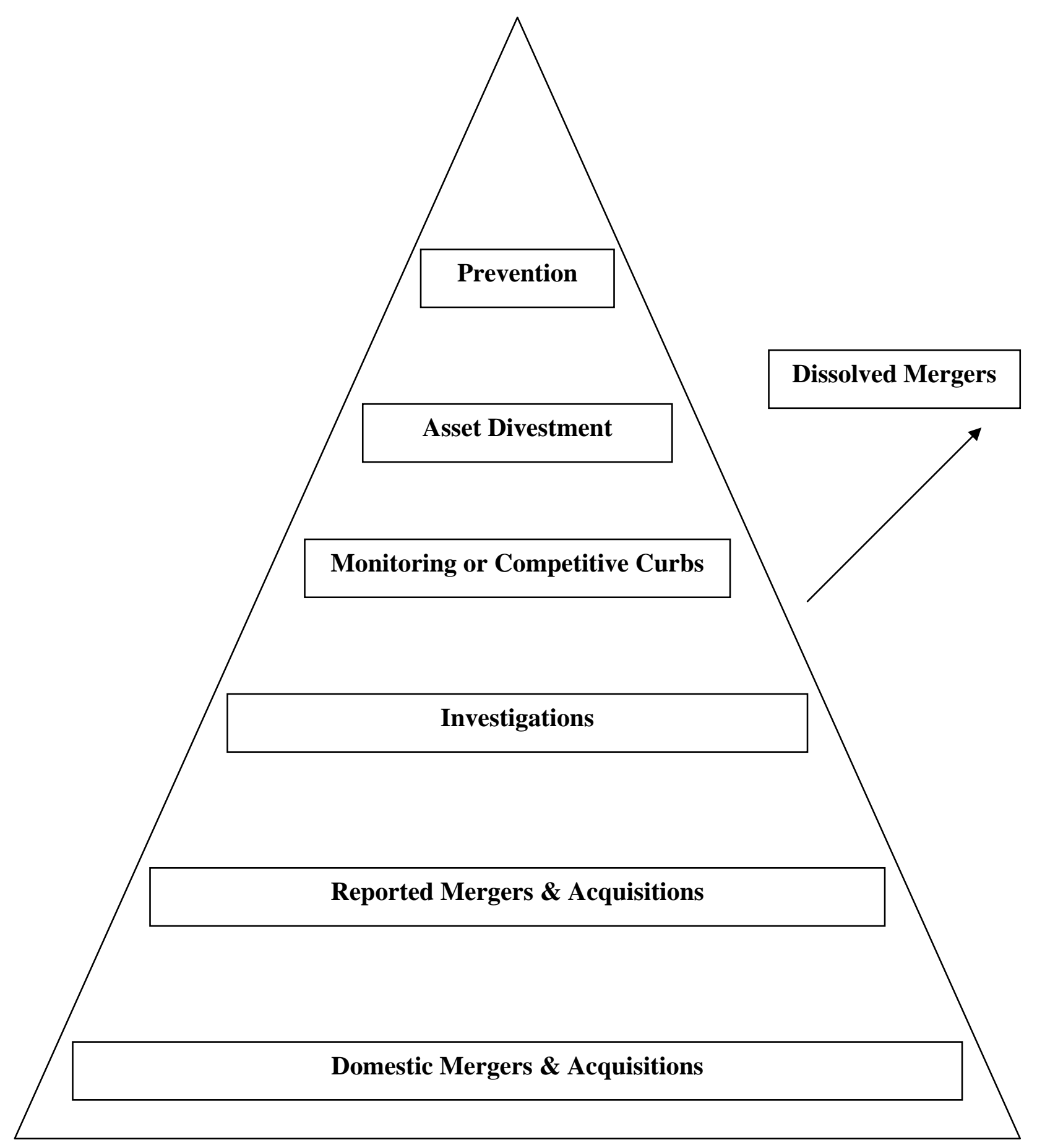




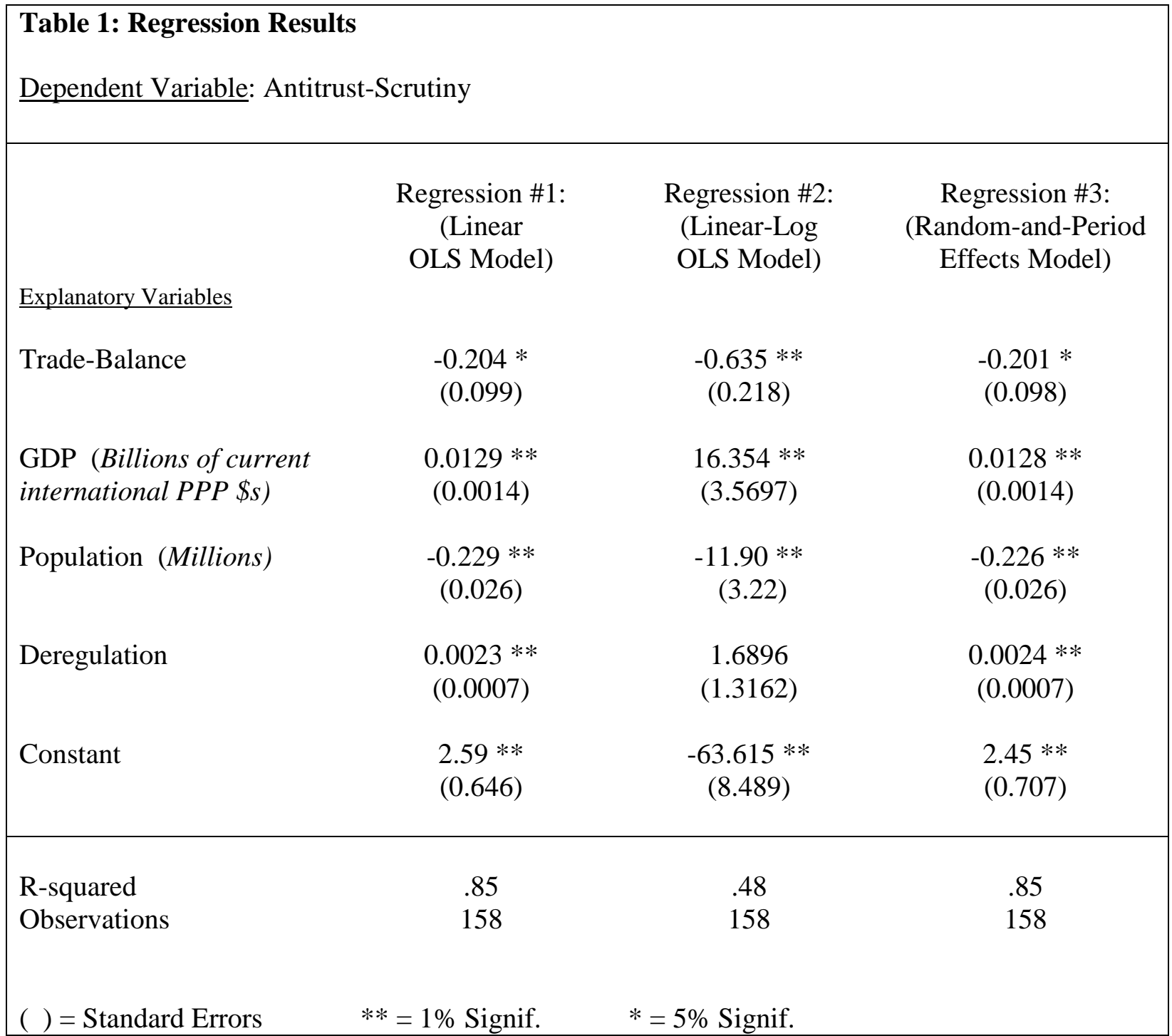


Bücher des Forschungsschwerpunkts Markt und politische Ökonomie

Books of the Research Area Markets and Political Economy

Pablo Beramendi

Decentralization and Income Inequality

2003, Madrid: Juan March Institute

Thomas Cusack

A National Challenge at the Local Level: Citizens, Elites and Institutions in Reunified Germany

2003, Ashgate

Sebastian Kessing

Essays on Employment Protection

2003, Freie Universität Berlin,

http://www.diss.fu-berlin.de/2003/202

Daniel Krähmer

On Learning and Information in Markets and

Organizations

2003, Shaker Verlag

Bob Hancké

Large Firms and Institutional Change. Industrial Renewal and Economic Restructuring in France 2002, Oxford University Press

Andreas Stephan

Essays on the Contribution of Public Infrastruc-

ture to Private: Production and its Political

Economy

2002, dissertation.de

Peter A. Hall, David Soskice (Eds.)

Varieties of Capitalism

2001, Oxford University Press

Hans Mewis

Essays on Herd Behavior and Strategic Delegation

2001, Shaker Verlag

Andreas Moerke

Organisationslernen über Netzwerke - Die

personellen Verflechtungen von Führungsgremien

japanischer Aktiengesellschaften

2001, Deutscher Universitäts-Verlag

Silke Neubauer

Multimarket Contact and Organizational Design

2001, Deutscher Universitäts-Verlag

Lars-Hendrik Röller, Christian Wey (Eds.)

Die Soziale Marktwirtschaft in der neuen

Weltwirtschaft, WZB Jahrbuch 2001

2001, edition sigma

Michael Tröge

Competition in Credit Markets: A Theoretic

Analysis

2001, Deutscher Universitäts-Verlag

Torben Iversen, Jonas Pontusson, David Soskice

(Eds.)

Unions, Employers, and Central Banks

2000, Cambridge University Press
Tobias Miarka

Financial Intermediation and Deregulation:

A Critical Analysis of Japanese Bank-Firm-

Relationships

2000, Physica-Verlag

Rita Zobel

Beschäftigungsveränderungen und

organisationales Lernen in japanischen

Industriengesellschaften

2000, Humboldt-Universität zu Berlin

http://dochost.rz.hu-berlin.de/dissertationen/zobel-rita2000-06-19

Jos Jansen

Essays on Incentives in Regulation and Innovation 2000, Tilburg University

Ralph Siebert

Innovation, Research Joint Ventures, and Multiproduct Competition

2000, Humboldt-Universität zu Berlin

http://dochost.rz.hu-berlin.de/dissertationen/siebert-

ralph-2000-03-23/

Damien J. Neven, Lars-Hendrik Röller (Eds.)

The Political Economy of Industrial Policy in

Europe and the Member States

2000, edition sigma

Jianping Yang

Bankbeziehungen deutscher Unternehmen:

Investitionsverhalten und Risikoanalyse

2000, Deutscher Universitäts-Verlag

Christoph Schenk

Cooperation between Competitors -

Subcontracting and the Influence of Information, Production and Capacity on Market Structure and Competition

1999, Humboldt-Universität zu Berlin

http://dochost.rz.hu-berlin.de/dissertationen/schenkchristoph-1999-11-16

Horst Albach, Ulrike Görtzen, Rita Zobel (Eds.)

Information Processing as a Competitive

Advantage of Japanese Firms

1999, edition sigma

Dieter Köster

Wettbewerb in Netzproduktmärkten

1999, Deutscher Universitäts-Verlag

Christian Wey

Marktorganisation durch Standardisierung: Ein

Beitrag zur Neuen Institutionenökonomik des

Marktes

1999, edition sigma 
Annette Boom

Kai A. Konrad Wolfram F. Richter

Stergios Skaperdas

Johan Lagerlöf

Roman Inderst

Christian Wey

Sebastian Kessing

Robert Nuscheler

Lars Frisell

Paul Heidhues

Nicolas Melissas

Pablo Beramendi

Daniel Krähmer

Ralph Siebert

Vivek Ghosal

Vivek Ghosal

Andreas Blume

Paul Heidhues

Sebastian Kessing

Tomaso Duso Astrid Jung

Thomas R. Cusack Pablo Beramendi

Kjell Erik Lommerud Frode Meland Odd Rune Straume Joseph Clougherty
Investments in Electricity Generating Capacity under Different Market Structures and with Endogenously Fixed Demand

Zur Berücksichtigung von Kindern bei umlagefinanzierter Alterssicherung

Restraining the Genuine Homo Economicus: Why the Economy cannot be divorced from its Governance

Insisting on a Non-Negative Price: Oligopoly, Uncertainty, Welfare, and Multiple Equilibria

Buyer Power and Supplier Incentives

Monopoly Pricing with Negative Network Effects: The Case of Vaccines

The Breakdown of Authority

Equilibria in a Dynamic Global Game: The Role of Cohort Effects

Political Institutions and Income Inequality: The Case of Decentralization

Learning and Self-Confidence in Contests

The Introduction of New Product Qualities by Incumbent Firms: Market Proliferation versus Cannibalization

Impact of Uncertainty and Sunk Costs on Firm Survival and Industry Dynamics

Endemic Volatility of Firms and Establishments: Are Real Options Effects Important?

Private Monitoring in Auctions

Delay in Joint Projects

Product Market Competition and Lobbying Coordination in the U.S. Mobile

Telecommunications Industry

Taxing Work: Some Political and Economic Aspects of Labor Income Taxation

Globalisation and Union Opposition to Technological Change

Industry Trade-Balance and Domestic Merger Policy: Some Empirical Evidence from the U.S.
SP || $2003-14$

SP || $2003-01$

SP || $2003-02$

SP II $2003-03$

SP || $2003-04$

SP II $2003-05$

SP || $2003-06$

SP || $2003-07$

SP || $2003-08$

SP || $2003-09$

SP || $2003-10$

SP || $2003-11$

SP || $2003-12$

SP || $2003-13$

SP || $2003-15$

SP || $2003-16$

SP || $2003-17$

SP || $2003-18$

SP || $2003-19$ 
Dan Anderberg Fredrik Andersson

Eugenio J. Miravete Lars-Hendrik Röller

Talat Mahmood Klaus Schömann

Talat Mahmood Klaus Schömann

Suchan Chae Paul Heidhues

Sigurt Vitols

Michal Grajek

Kai A. Konrad

Helmut Bester

Kai A. Konrad

Kai A. Konrad

Kai A. Konrad

Steffen Huck Kai A. Konrad
Stratification, Social Networks in the Labour Market, and Intergenerational Mobility

Estimating Markups under Nonlinear Pricing Competition

On the Migration Decision of IT-Graduates:

A Two-Level Nested Logit Model

Assessing the Migration Decision of Indian IT-Graduates: An Empirical Analysis

Buyers Alliances for Bargaining Power

Negotiated Shareholder Value: The German Version of an Anglo-American Practice

Estimating Network Effects and Compatibility in Mobile Telecommunications

Bidding in Hierarchies

Easy Targets and the Timing of Conflict

Opinion Leaders, Influence Activities and Leadership Rents

Mobilität in mehrstufigen Ausbildungsturnieren

Moral Cost, Commitment and Committee Size
SP || $2003-20$

SP || 2003- 21

SP || $2003-22$

SP || $2003-23$

SP || $2003-24$

SP || $2003-25$

SP || $2003-26$

SP || $2003-27$

SP || $2003-28$

SP || $2003-29$

SP || $2003-30$

SP || $2003-31$ 
Jos Jansen

Johan Lagerlöf

Lars Frisell

Sigurt Vitols

Lutz Engelhardt

Antonio Guarino

Steffen Huck

Thomas D. Jeitschko

Thomas Plümper

Vera E. Troeger

Ulrich Kaisera

Pablo Beramendi Thomas R. Cusack

Joseph Clougherty
Partial Information Sharing in Cournot Oligopoly

Lobbying, Information Transmission, and Unequal Representation

Changes in Germany's Bank Based Financial System: A Varieties of Capitalism Perspective

Entrepreneurial Business Models in the German Software Industry: Companies, Venture Capital, and Stock Market Based Growth Strategies of the ,Neuer Markt'

Can Fear Cause Economic Collapse? Insights from an Experimental Study

External Effects of Currency Unions

An Estimated Model of the German Magazine Market

Diverse Disparities: The Politics and Economics of Wage, Market and Disposable Income Inequalities

Antitrust Holdup Source, Cross-National Institutional Variation, and Corporate Political Strategy Implications for Domestic Mergers in a Global Context
SP II $2004-01$

SP || 2004-02

SP || $2004-03$

SP || 2004-04

SP || 2004- 05

SP || 2004-06

SP || $2004-07$

SP || $2004-08$

SP || 2004- 09 
Bei Ihren Bestellungen von WZB-Papers schicken

Sie bitte unbedingt einen an Sie adressierten Auf-

kleber mit sowie je paper eine Briefmarke im Wert

von 0,51 Euro oder einen "Coupon Reponse Inter-

national " (für Besteller aus dem Ausland)
Please send a self addressed label and postage stamps in the amount of 0.51 Euro or a "CouponReponse International" (if you are ordering from outside Germany) for each WZB-paper requested

Absender I Return Address:

Wissenschaftszentrum Berlin

für Sozialforschung

Presse- und informationsreferat

Reichpietschufer 50

D-10785 Berlin-Tiergarten

Hiermit bestelle ich folgende(s)

Discussion paper(s):

Please send me the following Discussion paper(s):

Bestell-Nr. I Order no.

Autor/in, Kurztitel /Author(s) / Title(s) in brief 